\title{
MANAGEMENT OF WASTE HEAT AT NUCLEAR POWER PLANTS: ITS POTENTIAL IMPACT ON THE ENVIRONMENT AND ITS POSSIBLE ECONOMIC USE*
}

\author{
by \\ Dr. Y.H. Tsai \\ Section Manager \\ Energy and Environmental Systems Division \\ Argonne National Laboratory \\ Argonne, Illinois, U.S.A.
}

\section{DISCLAIMER}

This report was prepared as an account of work sponsored by an agency of the United States Government. Neither the United States Government nor any agency thereof, nor any of their employees, makes any warranty, express or implied, or assumes any legal liability or responsiprocess disclosed, or represents that, or usefulness of any information, apparatus, product, or ence herein to any specific ence herein to any specific commercial product, process, or service by trade name, trademark, mendation, or or necessarily constitute or imply its endorsement, recommendation, or favoring by the United States Government or any agency thereof. The views United States Government or any agency do not necessarily state or reflect those of the *Work supported by U.S. Nuclear Regulatory Commission, Office of Nuclear
Reactor Regulation. 


\section{DISCLAIMER}

This report was prepared as an account of work sponsored by an agency of the United States Government. Neither the United States Government nor any agency Thereof, nor any of their employees, makes any warranty, express or implied, or assumes any legal liability or responsibility for the accuracy, completeness, or usefulness of any information, apparatus, product, or process disclosed, or represents that its use would not infringe privately owned rights. Reference herein to any specific commercial product, process, or service by trade name, trademark, manufacturer, or otherwise does not necessarily constitute or imply its endorsement, recommendation, or favoring by the United States Government or any agency thereof. The views and opinions of authors expressed herein do not necessarily state or reflect those of the United States Government or any agency thereof. 


\section{DISCLAIMER}

Portions of this document may be illegible in electronic image products. Images are produced from the best available original document. 
MANAGEMENT OF WASTE HEAT AT NUCLEAR POWER PLANTS:

ITS POTENTIAL IMPACT ON THE ENVIRONMENT AND

ITS POSSIBLE ECONOMIC USE

by

Dr. Y.H. Tsai

Section Manager

Energy and Environmental Systems Division

Argonne National Laboratory

Argonne, Illinois, U.S.A.

\section{ABSTRACT}

The efficacy of the disposal of waste heat from nuclear power plants by means of once-through and closed-cycle cooling systems is examined in the context of the physical aspects of water quality standards and guidelines for thermal discharges. Typical thermal standards for each of the four classes of water bodies (rivers, lakes, estuaries, and coastal waters) are identified. Examples of thermal standards established for once-through cooling on open coastal waters are presented.

The design and general layout of various types of cooling systems are reviewed. The advantages and disadvantages of each of the cooling systems are presented, with particular emphasis on the discussion of potential environmental impacts. Modeling techniques available for impact assessment are presented. Proper selection and application of the models depend on the availability of site characteristics and understanding of the modeling techniques. Guidelines for choosing an appropriate model are presented.

Various methods have been developed for the beneficial use of waste heat largely dissipated to the environment. Examples and associated problems of waste-heat utilization are discussed for agricultural, industrial, aquacultural, and residential uses. 
TABLE OF CONTENTS

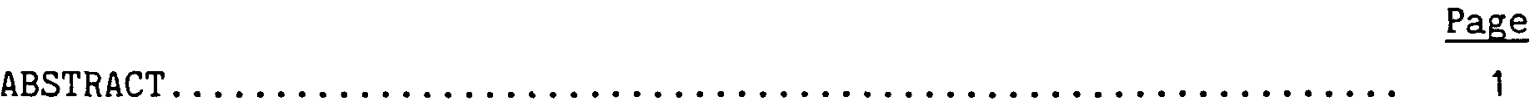

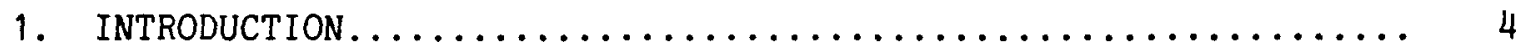

2. HEAT REJECTION REQUIREMENTS...................... 5

2.1 Efficiency and Heat Rejection of Nuclear Power Plant....... 6

2.2 Laws, Regulations, and Guidelines................ 7

2.2.1 U.S. Nuclear Regulatory Commission............... 7

2.2.2 U.S. Environmental Protection Agency.............. 8

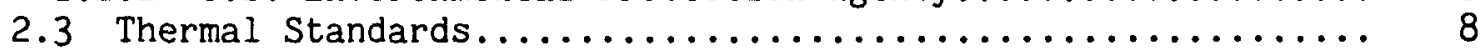

2.3.1 Development of Thermal Standards................ 8

2.3.2 Examples of Thermal Standards for Coastal Plants....... 11

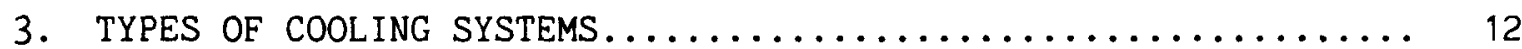

3.1 Once-Through Cooling Systems..................... 12

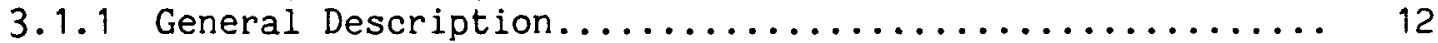

3.1.2 Types of Once-Through Intake Systems.............. 13

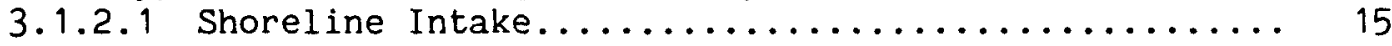

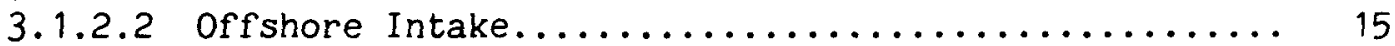

3.1.2.3 Approach Channel Intake.................... 16

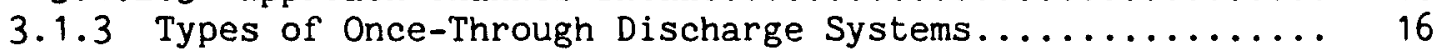

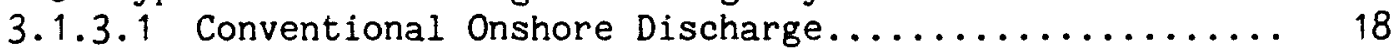

3.1.3.2 Dilution Pumping Discharge System............. 21

3.1.3.3 Single-Port Offshore Submerged Discharge.......... 21

3.1.3.4 Multiport Offshore Submerged Diffuser Discharge..... 25

3.2 Closed-Cycle Cooling Systems.................... 28

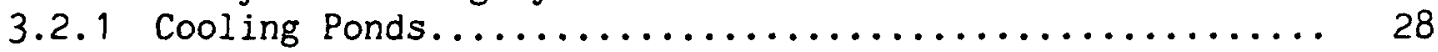

3.2.1.1 Classification of Cooling Ponds.............. 29

3.2 .1 .2 Design and Sizing of Cooling Ponds............. 30

3.2.2 Evaporative Cooling Tower Systems................ 31

3.2.2.1 Design and Performance Parameters............. 33

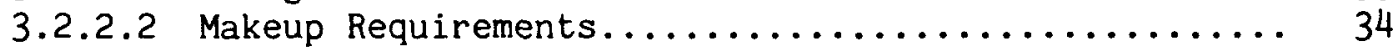

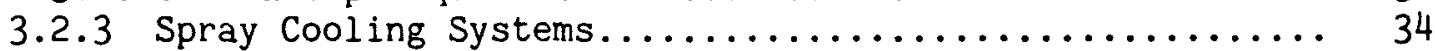

3.2 .4 Dry Cooling Tower Systems.................. 36

3.2.5 Potential for Using Seawater Closed-Cycle Cooling

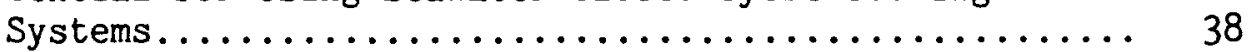

3.3 Cooling System Flow and Temperature Rise............. 39

4. ENVIRONMENTAL IMPACTS OF COOLING SYSTEMS.............. 42

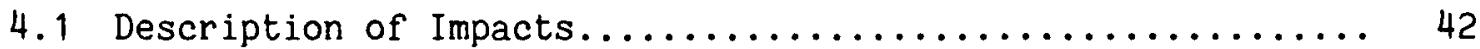

4.1 .1 Impacts of Once-Through Cooling Systems............ 42

4.1.1.1 The Effects of Passage Through the Power Plant..... 42

4.1.1.2 The Effects of Passage Through the Thermal Plume.... 43

4.1.1.3 The Effects of Regional Warming.............. 43 
4.1.2 Impacts of Closed-Cycle Cooling Systems............ 44

4.1.2.1 Hydrological and Aquatic Impacts.............. 45

4.1.2.2 Atmospheric and Terrestrial Impacts............. 45

4.1.2.3 Land-Use, Aesthetic, and Noise Impacts........... 45

4.2 Modeling Techniques for Impact Assessment.............. 46

4.2 .1 Model Application and Selection................ 46

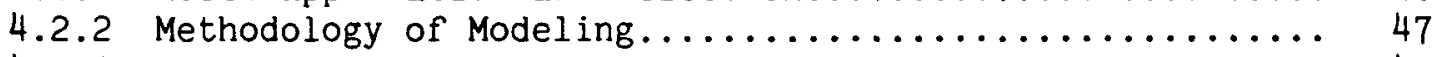

4.2 .3 Recommended Models....................... 47

5. BENEFICIAL USE OF WASTE HEAT..................... 49

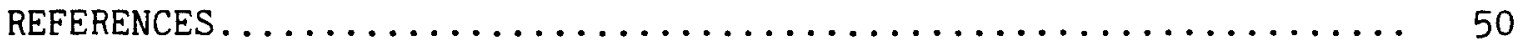




\section{INTRODUCTION}

Over the past decade, nuclear power plants have become the major source for generating electrical energy needed to support the growth of commerce, industry, and vast transportation systems in many countries. There are currently 537 nuclear units worldwide, with a total generating capacity of $414,000 \mathrm{MWe}$. The fast growth of nuclear power plants, however, has resulted in increasing concerns regarding their potential impacts on living environments. This paper deals principally with the impact of thermal discharges relative to the management of waste heat at nuclear power plants.

The production of electricity from nuclear power plants requires continual removal of significant amounts of waste heat by passing large quantities of cooling water through condensers. The heat absorbed by the cooling water must either be dissipated to the environment or recovered for beneficial use. This paper focuses on the development of and problems associated with the utilization of these two waste-heat management techniques.

Several alternative methods are available for the disposal of waste heat from nuclear power plants: (1) once-through cooling systems, and (2) closed-cycle cooling systems that include cooling ponds, spray systems, evaporative cooling towers, and dry towers (or hybrid combinations of these systems). Each of these alternative cooling methods has its advantages and disadvantages. Historically, once-through cooling systems have been selected for stations located on the open coast or on rivers or lakes having large heat-assimilation/dissipation characteristics. Although a site where this type of system is proposed must be carefully evaluated from an engineering and environmental standpoint, it is clear that the oceans as well as large rivers and lakes still offer a more satisfactory location for waste heat disposal. A site that is acceptable for once-through cooling must have several basic characteristics, including: (1) access to large quantities of water, (2) adequate flushing and dispersion to dissipate waste heat, and (3) an ecosystem that is not seriously affected by construction and operation of the power plant.

The methodologies -- field, laboratory, statistical, and modeling -used to assess the effects of the operation of power plant once-through cooling systems on aquatic ecosystems are being continually developed and refined. It is now recognized that the real technical question in impact assessment is often not the occurrence of some measurable effects but the capability of biological systems to resist, and to recover from, induced changes. At the population level this capability is termed compensation, and at the ecosystem level, resiliency.

The analysis of aquatic ecosystems by various methods has advanced to a stage where quantitative estimates can be obtained of the relative size of power plant-induced effects. These measures of the magnitude of effect can be compared to the size of the source populations involved. When a large proportion of a population is being affected, the ability of 
the population to resist or recover from induced change is of concern. Evaluation of the compensatory response of the population, or the resilience of the ecosystem, can form the basis for a professional judgment regarding the potential for or existence of an environmental impact.

For sites where the aquatic ecosystem or available water supply precludes the use of once-through cooling, it is necessary to use closedcycle cooling. As in the case of once-through cooling, this too requires consideration of water supply adequacy and environmental impacts. The aquatic impacts of makeup and blowdown to the closed-cycle system should be included in site evaluation as well as terrestrial and aesthetic impacts.

Regulatory and institutional factors may also influence the selection of a cooling system for a particular site. For example, water use restrictions or water quality criteria in some areas may preclude the use of once-through cooling.

The potential beneficial uses of thermal discharges have been widely studied. Various methods have been developed for agricultural, industrial, aquacultural, and residential use of energy largely wasted to the environment. There are, however, problems associated with waste-heat utilization.

\section{HEAT REJECTION REQUIREMENTS}

Heat generated by the process of controlled nuclear fission in a nuclear reactor is transformed into usable energy by a suitable fluid that either directly or indirectly powers a turbine to generate electricity. For most nuclear power plants, the working fluid is water (and steam) that is circulated through various loops to complete the thermodynamic cycle.

It is a fundamental law of thermodynamics that to produce useful work, heat must be exchanged with the environment. At the exhaust of the turbine, steam is condensed to water and then directly or indirectly returned to the reactor to complete the thermodynamic cycle. Condenser cooling water or circulating water is used to extract waste heat from the cycle. The thermodynamic efficiency of the energy conversion cycle depends on the temperature difference between the hot working steam and the condenser cooling water used to condense the steam. Hotter steam or colder coolant will increase the cycle efficiency and, therefore, decrease the waste heat.

Waste heat from an electric power plant must eventually be dissipated to the environment. In practice, most of it ultimately is transferred to the atmosphere. Water is commonly used as the heat transfer fluid because of its general abundance, low cost, high specific heat, and ability to dissipate heat in the evaporation process. 
For power plants with cooling towers, heat is transferred directly to the ambient air. For most coastal-sited plants, seawater is used in once-through cooling systems to provide the condenser cooling/heat dissipation function.

\subsection{EFFICIENCY AND HEAT REJECTION OF A NUCLEAR POWER PLANT}

The efficiency of electric power production by nuclear fuel is governed by the thermodynamics of the heat cycle. The ideal or Carnot efficiency is determined by the temperature of the heat source ( $\mathrm{T}_{\text {source }}$ ) and by the temperature of the surrounding air or water which acts as a heat sink $\left(T_{\text {sink }}\right)$. The ideal efficiency is given by

$$
E_{i}=1-\frac{T_{\text {sink }}}{T_{\text {source }}} 100
$$

where the temperatures are measured on an absolute scale. In a boilingwater reactor (BWR) or pressurized-water reactor (PWR) unit, maximum temperatures are about $315^{\circ} \mathrm{C}\left(590^{\circ} \mathrm{K}\right)$ and the average annual heat sink may be $15^{\circ} \mathrm{C}\left(290^{\circ} \mathrm{K}\right)$; thus the ideal efficiency is approximately $51 \%$. The temperature of the heat sink would have to approach absolute zero $\left(-273^{\circ} \mathrm{C}\right)$ in order for the ideal efficiency to approach $100 \%$. As in all mechanical and thermodynamic processes, the working efficiency is less than the ideal. Nuclear power plants achieve about $62 \%$ of the Carnot cycle efficiency for an overall thermal efficiency $\left(E_{t}\right)$ of about $32 \%$. Thus, for each unit of electric energy generated, the equivalent of two units of energy is rejected to the surrounding air or water in the form of heat. given by

The overall thermal efficiency $\left(E_{t}\right)$ of a steam electric plant is

$$
E_{t}(\%)=\frac{\text { Electrical Output }}{\text { Thermal Input }} \times 100
$$

The denominator of the above efficiency equation is known as the "heat rate" of a plant. This is defined as the average amount of heat required to produce one kilowatt-hour of electrical energy.

The heat rejected in the condenser cooling system is generally less than the total waste heat produced by the plant because of in-plant losses. If it is assumed that in-plant losses are a constant fraction (represented by $\delta$ ) of the fuel heat content, then heat rejection in condenser cooling water $\left(\mathrm{MW}_{\mathrm{c}}\right)$ can be written as

$$
M W_{c}=\frac{M W_{e}}{E_{t}}\left(1-E_{t}-\delta\right)
$$

in which $\mathrm{MW}_{\mathrm{e}}=$ electrical output, in megawatts. In a 1,000-MW nuclear (BWR or PWR) plant, $E_{t}=32 \%$ and in-plant losses are approximately $\delta=$ 
5\%; thus, $M W_{c}=1970 \mathrm{MW}$. This is equivalent to $6.7 \times 10^{9} \mathrm{Btu} / \mathrm{h}$. (Note: $1 \mathrm{~kW}=3,413 \mathrm{Btu} / \mathrm{h}$.$) .$

The rate at which waste heat is delivered to the condenser cooling water system can be related to the cooling-water flow rate $\left(Q_{c}\right)$ and the resulting temperature $\mathrm{rise}\left(\Delta \mathrm{T}_{c}\right)$ by

$$
M W_{c}=\rho C_{h} Q_{c} \Delta T_{c}
$$

in which $\rho=$ density of water and $C_{h}=$ heat capacity of water.

Equation 2.4 can also be written as

$$
K\left(M_{c}\right)=Q_{c} \Delta T_{c}
$$

where

$$
K=0.47 \frac{\left(\mathrm{m}^{3} / \mathrm{s}\right) \mathrm{C}^{0}}{\mathrm{MW}}
$$

for nuclear plants (Paddock and Ditmars 1978).

A typical condenser water flow rate for a $1,000-\mathrm{MW}$ unit is about $47 \mathrm{~m} 3 / \mathrm{s}$. Based on this flow rate and Eqs. 2.5 and 2.6 , the temperature increase through the condenser is $10.0^{\circ} \mathrm{C}$. This figure is based on the current state of technology; however, most authorities see little likelihood of a significant increase in power cycle efficiencies within the next decade or two. Even if a major change in efficiency were to occur, it would be quickly overcome by the growth curve for electrical energy.

\subsection{LAWS, REGULATIONS, AND GUIDELINES}

Heat dissipation systems interact directly with the environment and consequently have potential environmental effects associated with their construction and operation. This fact has been recognized by the various government agencies who have established environmental regulations applicable to cooling systems. This section provides a summary of the major federal environmental laws, regulations, and guidelines most applicable to cooling systems.

\subsubsection{U.S. Nuclear Regulatory Commission}

Since enactment of the National Environmental Policy Act of 1969, the U.S. Nuclear Regulatory Commission (USNRC) has required utility companies to submit detailed environmental reports, including consideration of alternatives, to apply for construction and operating permits. In the environmental reports, USNRC requires an applicant to address the potential environmental impacts of the proposed cooling system and alternative cooling systems. Those impacts to be considered include aquatic, atmospheric, terrestrial, aesthetic, and social. 
USNRC Regulatory Guide 4.2, "Preparation of Environmental Reports for Nuclear Power Stations," provides the primary guidance for preparation of environmental reports. Chapters 3, 4, 5, and 6 of Reg. Guide 4.2 include cooling system design and impact considerations whereas Chapter 10 addresses the requirements to compare alternative cooling systems.

Other USNRC Regulatory Guides that influence cooling system design and impact assessment include Guide 4.4, "Reporting Procedure for Mathematical Models Selected to Predict Heated Effluent Dispersion in Natural Water Bodies," and Guide 4.7, "General Site Suitability Criteria for Nuclear Power Stations."

\subsubsection{U.S. Environmental Protection Agency}

The U.S. Environmental Protection Agency (USEPA) has been granted authority to regulate and control discharges to the environment. Accordingly, the following laws and regulations apply to power plant cooling systems.

The Federal Water Pollution Control Act Amendments of 1972 and Clean Water Act Amendments of 1977 are intended to restore and preserve the nation's water quality. Under the authority granted by these laws, the USEPA has published Effluent Guidelines and Standards that apply to cooling water discharges. These guidelines are found in Title 40, Code of Federal Regulations, Part 423 (40 CFR 423), "Steam Electric Power Generating Point Source Category."

The Clean Air Act Amendments of 1970 and 1977 also influence power plant cooling systems. The act affects nuclear power plant siting and design by regulating the amount and type of air pollutants that can be emitted from a facility. Permit restrictions imposed under this act can limit the discharge of total suspended particulates that are emitted from cooling towers -- particularly, brackish (or saltwater) towers or towers with high concentration ratios.

\subsection{THERMAL STANDARDS}

\subsubsection{Development of Thermal Standards}

The Water Quality Act of 1965, which amended the Federal Water Pollution Control Act of 1956, specified that water quality criteria and standards be developed. The National Technology Advisory Committee (NTAC) to the U.S. Secretary of the Interior developed water quality criteria and published its recommendations in April 1968 (Natl. Technol. Adv. Comm. 1968). In the meantime, individual states instituted, with the approval of the Secretary of the Interior, their own standards for the various aspects of water quality including temperature. In 1970, the duty of overseeing the institution of standards by individual states was transferred to the Administrator of the USEPA. By 1971, most states had some form of approved standards for maximum temperature. Maximum temperature restrictions ranged from $60.0^{\circ} \mathrm{F}\left(15.6^{\circ} \mathrm{C}\right)$ to $96.8^{\circ} \mathrm{F}\left(36.0^{\circ} \mathrm{C}\right)$ 
depending upon the state and the type of water body. Maximum allowable temperature increases above ambient ranged from 0 to $20.0^{\circ} \mathrm{F}$ ( 0 to $11.1^{\circ} \mathrm{C}$ ) depending on the type of water body and its natural temperature.

The NTAC also set forth recommendations for temperature standards within their water quality criteria. They recommended a maximum permissible temperature rise above naturally existing temperatures of $5.0^{\circ} \mathrm{F}\left(2.8^{\circ} \mathrm{C}\right)$ for streams and $3.0^{\circ} \mathrm{F}\left(1.7^{\circ} \mathrm{C}\right)$ for lakes. They also recommended that cold-water fisheries (trout and salmon waters) not be disturbed. In marine and estuarine environments, they recommended that monthly maximum daily temperatures at a site not be raised by more than $4.0^{\circ} \mathrm{F}\left(2.2^{\circ} \mathrm{C}\right.$ ) in winter (September-May) or more than $1.5^{\circ} \mathrm{F}\left(0.8^{\circ} \mathrm{C}\right.$ ) in summer (June-August). In addition, the NTAC recommended that mixing zones should be as small as possible and should be determined on a caseby-case basis. A mixing zone is a region near the discharge structure within which the excess temperature standards do not apply (that is, within which standards may be exceeded).

The USEPA evaluated the state standards and attempted to guide the states in revising their standards so as to be more precise and uniform. The USEPA supported the NTAC recommendations and used them as guidelines in this effort. As a result, many state standards reflect these recommendations.

In 1972, the U.S. Congress adopted the Federal Water Pollution Control Act Amendments (Public Law 92-500). The Act sets the goal of eliminating the discharge of pollutants into navigable waters by 1985 (Section 101); waste heat is specifically included as a pollutant. Section 301 of the Act is concerned with existing sources of pollution and requires the application of the best practicable control technology currently available by July 1, 1977, and the application of the best available technology economically achievable (BATEA) by July 1, 1983. Section 306 of the Act states that new sources must employ "the best available demonstrated control technology, process, operating methods, or other alternatives, including, where practicable, a standard permitting no discharge of pollutants." The USEPA interprets "best available technology" for the dissipation of waste heat at large (>25 MW) steamelectric power plants to be closed-cycle evaporative cooling. Section 316(a) of the Act, however, applies specifically to waste heat and authorizes the Administrator of the USEPA to impose alternative effluent limitations on a case-by-case basis such that the "protection and propagation of a balanced indigenous population of shellfish, fish and wildlife" in and on the receiving water body can be assured.

The USEPA has developed guidelines for the preparation of documents to support a request for a Section $316(a)$ exemption (U.S. Environ. Prot. Agency 1977). Among other things, these guidelines essentially require that the physical characteristics of the thermal plume be documented, based on either field measurements in the case of existing discharges or engineering estimates in the case of proposed discharges. A survey conducted by National Economic Research Associates, Inc. (1978), of power plants using or intending to use open-cycle cooling systems as of the end 
of 1977 showed that 59.3\% (by generating capacity) had applied for Section 316(a) exemptions. Of the exemptions applied for, $41.5 \%$ (by capacity) had been granted, $57.2 \%$ were pending, and $1.3 \%$ had been denied.

State water quality standards vary from state to state, and many have undergone review by the USEPA. As noted above, many are patterned after the recommendations of the NTAC. The maximum allowable temperature rises above ambient outside a mixing zone near the discharge point are summarized in Table 2.1 for various types of water bodies.

Table 2.1. Typical Excess Temperature (Above Ambient) Standards as Recommended by the NTAC

\begin{tabular}{lcc}
\multicolumn{1}{c}{ Water Body } & $\Delta \mathrm{T}_{\max }\left({ }^{\circ} \mathrm{F}\right)$ & $\Delta \mathrm{T}_{\max }\left({ }^{\circ} \mathrm{C}\right)$ \\
\hline Streams and Rivers & 5.0 & 2.8 \\
Lakes & 3.0 & 1.7 \\
Estuaries and Marine & & \\
$\quad$ Coastal Waters - & & \\
$\quad$ Winter & 4.0 & 2.2 \\
$\quad$ Summer & 1.5 & 0.8 \\
\hline
\end{tabular}

Mixing zone limitations were not specified explicitly by the NTAC but are to be determined on a case-by-case basis. As a guideline, in the case of streams, the mixing zone should be limited to less than $25 \%$ of the crosssectional area or of the volume flow of the stream. In general, the maximum distance, in feet, to the edge of the mixing zone in any direction should not exceed the number obtained by multiplying the numerical value of the square root of the discharge flow rate, in millions of gallons per day, by 200; and in no case to exceed 5,280 ft. In S.I. units, this limit can be expressed as:

$$
\begin{aligned}
L_{m z} & <\sqrt{Q_{p} /\left(1.2 \times 10^{-5} \mathrm{~m} / \mathrm{s}\right)} \text { for } Q_{p}<30 \mathrm{~m}^{3} / \mathrm{s} \text {, and } \\
<1,600 \mathrm{~m} & \text { for } Q>30 \mathrm{~m}^{3} / \mathrm{s}
\end{aligned}
$$

where $L_{m z}=$ maximum extent of mixing zone and $Q_{p}=$ discharge flow rate of the plant. This recommendation is considerably more relaxed than that suggested by many state regulations. In fact, most state regulations specify that the mixing zone be established on a case-by-case basis. 
When mixing zones are defined, they are often stated in terms of surface areas or areas equivalent to circles of specified radii. The specified radii typically range from $91 \mathrm{~m}(300 \mathrm{ft})$ to $305 \mathrm{~m}(1000 \mathrm{ft})$. The corresponding surface areas range from $2.6 \times 10^{4} \mathrm{~m}^{2}(6.5$ acres $)$ to $2.9 \times$ $10^{5} \mathrm{~m}^{2}(72$ acres $)$.

\subsubsection{Examples of Thermal Standards for Coastal Plants}

The San Onofre nuclear generating station is located on the Pacific Coast of southern California in San Diego County. The station comprises three pressurized-water reactors with a total electrical output of 2,660 MWe. Plant waste heat is dissipated by means of a separate oncethrough cooling system for each unit. About $53.5 \mathrm{~m}^{3} / \mathrm{s}(1,887 \mathrm{cfs})$ of seawater per unit is withdrawn from the ocean for condenser cooling at Units 2 and 3 . Only $21.6 \mathrm{~m}^{3} / \mathrm{s}(760 \mathrm{cfs})$ of seawater is used by Unit 1 which, after passing through the condenser, is discharged to the ocean through a submerged concrete conduit located about $790 \mathrm{~m}(2,600 \mathrm{ft})$ from shore. Condenser cooling waters from both Units 2 and 3 are discharged into the ocean by the offshore multiport diffuser located about $975 \mathrm{~m}$ $(3,200 \mathrm{ft})$ from shore. Operating experience indicates that the cooling water temperature increase ranges from 18 to $23^{\circ} \mathrm{F}\left(10\right.$ to $\left.12.8^{\circ} \mathrm{C}\right)$. The plume temperatures are required to meet California thermal standards, which specify that the $4^{\circ} \mathrm{F}\left(2.2^{\circ} \mathrm{C}\right)$ excess temperature isotherm never reach the shoreline or bottom and that the $4^{\circ} \mathrm{F}\left(2.2^{\circ} \mathrm{C}\right)$ surface isotherm must be within $305 \mathrm{~m}(1,000 \mathrm{ft})$ of the discharge point during at least one-half of the tidal cycle.

The Brunswick nuclear power plant is located on the Atlantic Coast near Southport, North Carolina. The plant comprises two boiling-water reactors with a rated generating capacity of 1,580 MWe. The design cooling water flow for the two units is approximately $82.2 \mathrm{~m} / \mathrm{s}$ $(2,900 \mathrm{cfs})$. The increase in temperature of water passing through the condensers normally ranges from 12 to $18^{\circ} \mathrm{F}\left(6.7\right.$ to $\left.10^{\circ} \mathrm{C}\right)$. The cooling water is discharged at a velocity of about $3 \mathrm{~m} / \mathrm{s}$ (10 fps) through two $4-\mathrm{m}$ $(13-f t)$ diameter concrete pipes that terminate $600 \mathrm{~m}(2,000 \mathrm{ft})$ offshore from nearby Oak Island. The plant has a wastewater discharge permit that was issued by the North Carolina Board of Water and Air Resources. The permit specifies temperature standards of a $1.5^{\circ} \mathrm{F}\left(0.83^{\circ} \mathrm{C}\right)$ increase above ambient water temperature during the months of June through August and a $4^{\circ} \mathrm{E}\left(2.2^{\circ} \mathrm{C}\right)$ increase above ambient water temperature during the months of September through May, except within (1) a mixing zone not to exceed $7^{\circ} \mathrm{F}$ $\left(3.9^{\circ} \mathrm{C}\right)$ above ambient temperature outside an area of $2.5 \times 10^{5} \mathrm{~m}^{2}$ (60 acres), (2) a mixing zone not to exceed the standards outside an area of $4.0 \times 10^{6} \mathrm{~m}^{2}(1,000$ acres $)$ having a boundary not closer than $152 \mathrm{~m}$ $(500 \mathrm{ft})$ to the beach, and (3) a mixing zone not to exceed the standards 
at $0.3 \mathrm{~m} \mathrm{(} \mathrm{ft}$ ) above the ocean floor for more than $152 \mathrm{~m}$ (500 ft) nor for an area of more than $8,000 \mathrm{~m}^{2}$ (2 acres).

The Shoreham nuclear power station is located on Long Island in the state of New York. The plant electrical output is 820 MWe. Cooling water with a temperature rise of $19.5^{\circ} \mathrm{F}\left(10.8^{\circ} \mathrm{C}\right)$ is discharged into Long Island Sound through a single-port diffuser. The New York State Water Quality Criteria governing thermal discharges for coastal water state that the receiving water temperature shall not be raised by more than $4^{\circ} \mathrm{F}$ $\left(2.2^{\circ} \mathrm{C}\right)$ from October through June, nor more than $1.5^{\circ} \mathrm{F}\left(0.83^{\circ} \mathrm{C}\right)$ from July through September, over that which existed before the addition of heat of artificial origin. However, this temperature may be exceeded within a radius of $91.4 \mathrm{~m} \mathrm{(300} \mathrm{ft)} \mathrm{from} \mathrm{the} \mathrm{point} \mathrm{of} \mathrm{discharge} \mathrm{or} \mathrm{equivalent} \mathrm{area}$ of about $26,300 \mathrm{~m}^{2}(6.5$ acres $)$.

The St. Lucie plant is located on Hutchinson Island about half-way between the cities of Fort Pierce and Stuart on the east coast of the state of Florida. The plant has two pressurized-water reactors; each has an electrical output of 780 MWe. The design cooling water flow is about $32.6 \mathrm{~m}^{3} / \mathrm{s}(1,150 \mathrm{cfs})$ per unit, and temperature rises range from 21 to $24^{\circ} \mathrm{F}\left(11.7\right.$ to $\left.13.3^{\circ} \mathrm{C}\right)$. Heated water leaving the condenser is discharged into the Atlantic Ocean through a submerged multiport diffuser located about $760 \mathrm{~m}(2,500 \mathrm{ft})$ from shore. Thermal standards specified by the Florida Department of Pollution Control are similar to the standards established for the San Onofre station in California.

\section{TYPES OF COOLING SYSTEMS}

The cooling systems available for the immediate disposal of the waste heat generated from the power plants can be classified into two basic systems: once-through cooling systems and closed-cycle cooling systems. The closed-cycle cooling systems include cooling ponds, spray cooling, evaporative cooling towers, and dry cooling towers. Each of the cooling systems has its advantages and disadvantages. Descriptions of the cooling systems are provided in the following sections.

\subsection{ONCE-THROUGH COOLING SYSTEMS}

\subsubsection{General Description}

The once-through cooling systems withdraw cooling water from a nearby water body (river, lake, reservoir, estuary, or open coastal region), pass the water through condensers, and return it directly to the water body at an elevated temperature. These systems normally have the lowest construction and maintenance costs. In such systems, incoming 
cooling water temperatures are typically the lowest practical, leading to increased thermal efficiency, and cooling water pumping power requirements are generally at a minimum. However, discharge of large quantities of heated water to the natural water bodies could possibly lead to large-scale modifications of the thermal regime and have a direct effect on the ecological system of the water body. Water consumption is minimal, but not negligible, due only to the increased evaporation from the water body caused by the elevated temperature. It is estimated that the increase in evaporation rate is equivalent to about 0.86 of the total cooling water requirement of the plant (Fed. Energy Reg. Comm. 1978). For example, a typical 1,000-MW nuclear power plant might cause an increase in the evaporation rate of $0.4 \mathrm{~m} / \mathrm{s}(14.1 \mathrm{cfs})$. Land requirements for once-through cooling systems are negligible relative to other cooling systems.

Various approaches have been used in the design of existing and proposed once-through cooling systems for the disposal of waste heat. Systems may use large cooling water flow rates and small temperature rises or small flow rates and large temperature rises to accommodate waste heat loads. The discharges may have high or low velocities; they may be located at the shoreline or offshore; they may be at the water surface or submerged; or they may have a single port or multiple ports. The approach depends on the type of water body, the size of the plant, and the costs of construction, operation, and maintenance. In addition, environmental constraints are usually imposed and of ten a judgment must be made as to which approach will result in the smallest detrimental impact to the environment.

\subsubsection{Types of Once-Through Intake Systems}

The selection and design of intake system require the consideration of several factors including (1) shoreline configuration; (2) water depth; (3) hydrographic conditions; (4) navigation channel; (5) construction cost; (6) aquatic environmental considerations; (7) location of discharge structure; and (7) plant operation and safety functions.

As shown in Figure 3.1, there are three general classifications of conventional intakes based on the relationship of the intake location relative to the water source: (1) shoreline intake, (2) offshore intake, and (3) approach channel intake. The first type of intake has the inlet flush with the shoreline. The second type of intake has the inlet located offshore with a conduit leading to the shore. The third type of intake uses an open approach channel inlet (generally excavated) leading to an inland water screening facility. This latter type of intake may also be referred to as an onshore intake. 


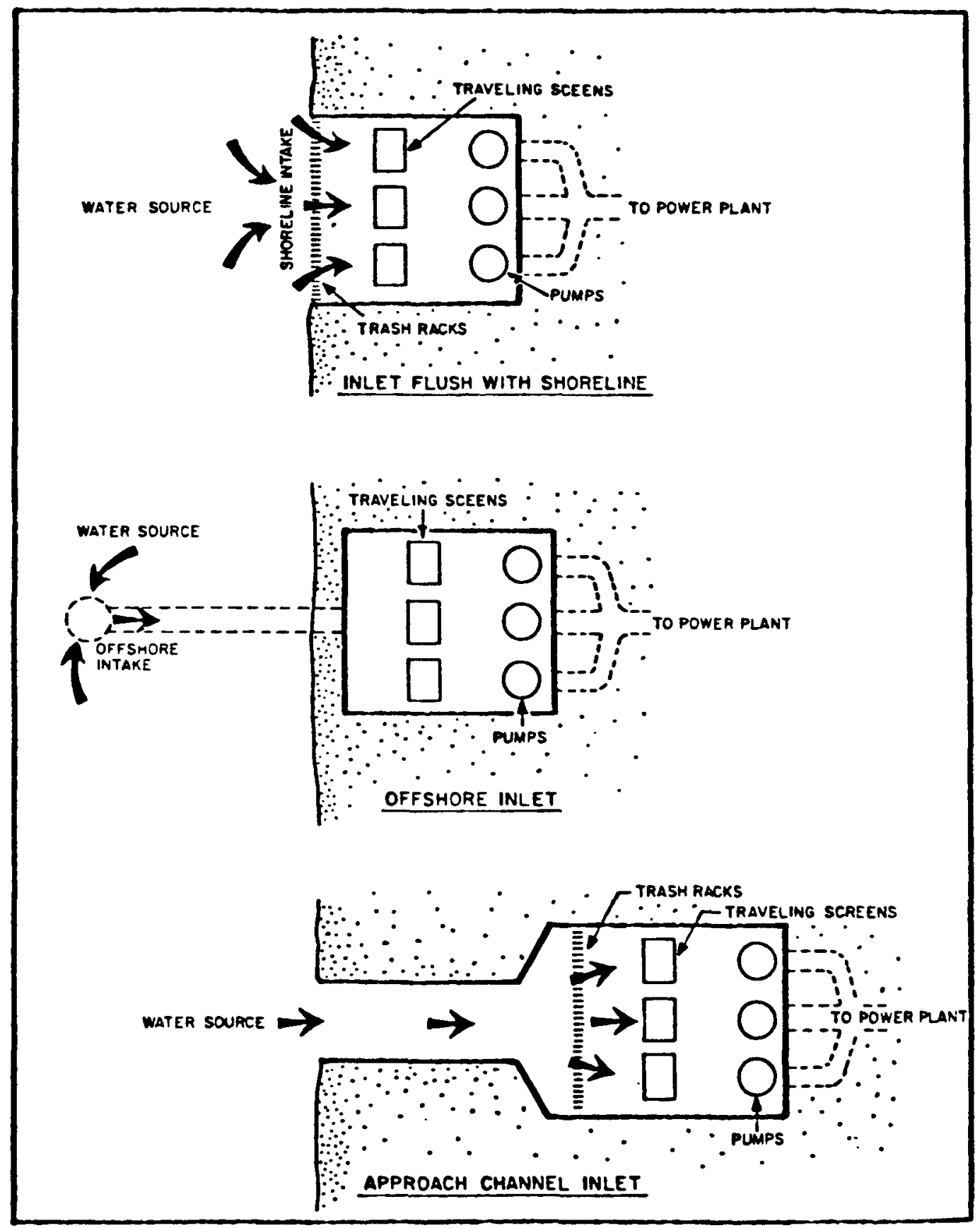

Figure 3.1. Three Types of Cooling Water Intake Structures. Source: U.S. Environmental Protection Agency (1977). 
Depending on local site and shoreline features, not all intake configurations may be applicable. For example, the inlet flush with the coastline may not be feasible if water depths are very shallow adjacent to the shore. Offshore intakes are not feasible if they interfere with navigation channels or other existing water uses.

Local hydrographic conditions can influence selection of intake location. For example, active near-shore sediment transport and littoral drift can cause substantial problems for flush shoreline and canal intakes. Offshore intakes can often be located in areas of less sediment transport, thus alleviating sediment entrainment problems and minimizing interference with near-shore sediment processes. Water temperature is another hydrographic consideration affecting intake location. It is desirable to obtain the coolest possible water to maximize plant efficiency. To this effect, considerable attention should be given to avoiding the inadvertent recirculation of warm water discharged back into the intake. From a fish attraction standpoint, the avoidance of recirculation is also advantageous. Long experience has shown that many species of fish tend to congregate in warm water areas, especially in the cooler seasons of the year.

Interference with established navigation channels is clearly undesirable and is an obvious consideration influencing intake location. The reliability of the inlet may be compromised if it is subject to ship collision, and disruption of established navigation routes is unlikely to be approved by regulatory authorities.

\subsubsection{Shoreline Intake}

The most common intake arrangement for shoreline intake is the combination of inlet, screen well, and pump well into a single structure on the edge of a water body. The best designation for this installation is "pump and screen structure", to clearly distinguish it from individual structures also commonly used. Under this design, the water on its way to the pumps passes through (in order) the trash rack, the stop log guide, and the traveling water screens. This type of arrangement is used where the slope of the river bank is relatively steep and there is relatively little movement of the water line between high and low water. A skimmer wall is often used to ensure drawing in of cooler, lower strata water. Walls used primarily to protect trash rocks and screens from logs and ice can also be used to draw in cooler water.

\subsubsection{Offshore Intake}

The offshore intake design separates the inlet from the pump well. This type of intake is used where there is a particular technical or environmental reason for utilizing the water supply at a distance from shore. 
Experience with offshore inlet structures along the coast of the state of California indicates that a horizontal inflow current has much less potential for fish entrapment than a vertical current (Weight 1958; Downs and Meddock 1974; Schuler and Larson 1974, 1975). A horizontal inflow direction is maintained about an inlet structure by means of a "velocity cap" as shown in Figure 3.2. This is a combination of a flat plate positioned just above the opening to the vertical inlet shaft and a flange at the top of the vertical inlet shaft of the same diameter as the "cap". The "velocity cap" allows inflowing water to enter the gap between the cap and the flange from only a horizontal direction. The nominal inflow velocity at the outer edge of the "velocity cap" varies from as low as $0.3 \mathrm{~m} / \mathrm{s}(1.0 \mathrm{fps})$ to about $0.9 \mathrm{~m} / \mathrm{s}(3.0 \mathrm{fps})$.

\subsubsection{Approach Channel Intake}

For the approach channel type of intake, cooling water is diverted from the shoreline to flow through a canal at the end of which is the screening device. Channel intakes have often been used to separate the plant intake and outfall for the control of recirculation effects, to permit location of the pump structure where it can more easily be constructed, or to reduce total system friction losses and costs by replacing high friction, high cost pipe with low friction, low cost canals. It may also be used to remove the intake from the shoreline for aesthetic reasons.

However, because fish tend to congregate in these approach channels, the channel intakes tend to increase the possibility of fish entrapment. To alleviate this problem, a possible modification of the approach channel concept is to place the screen structure at the entrance to the channel. This becomes essentially a shoreline intake, without the fish entrapment hazards inherent in the channel scheme. Shorelinelocated screens must be carefully designed to avoid velocities that could increase impingement. In certain cases, approach channels may be helpful in achieving uniform approach velocities.

\subsubsection{Types of Once-Through Discharge Systems}

There are many design alternatives for once-through cooling water discharge. The applicability of any particular system is of course based on site-specific conditions. In this paper, four basic discharge types will be reviewed: (1) conventional onshore discharge; (2) dilution pumping discharge; (3) single-port offshore submerged diffuser discharge, and (4) multiport offshore submerged diffuser discharge. 


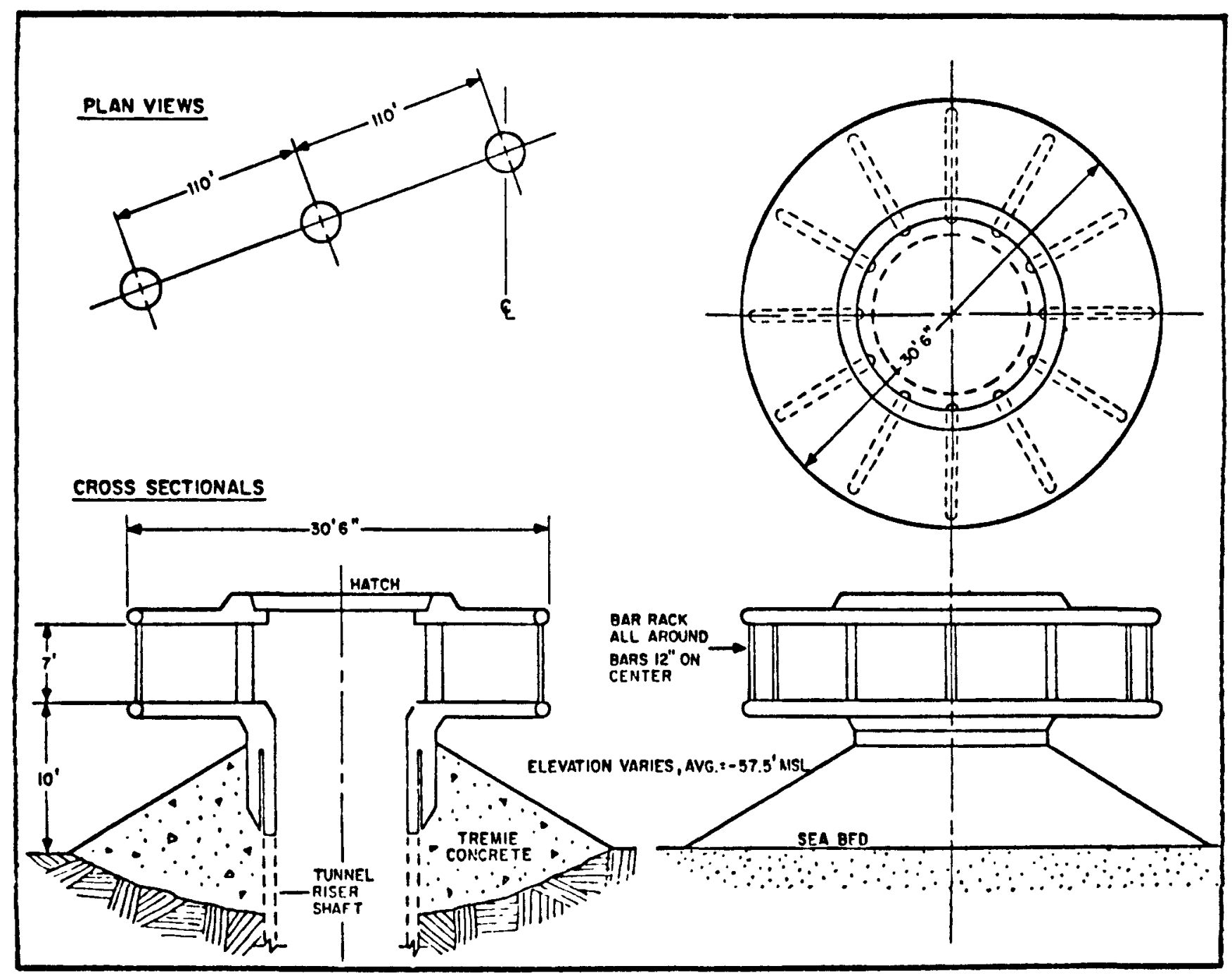

Figure 3.2. Velocity Cap Offshore Submerged Inlet Structure. Source: U.S. Environmental Protection Agency (1977). 


\subsubsection{Conventional Onshore Discharge}

The conventional onshore discharge system consists of a shoreline outfall structure that discharges cooling water in the shallow near-shore zones. Some such discharges have long riprap jetties extending offshore to direct the cooling water away from the intake structure. Other onshore discharge structures simply discharge directly into the nearshore waters. Figures 3.3 and 3.4 illustrate some typical onshore discharge concepts.

If near-shore water depths are particularly shallow, it may be necessary to provide an apron at the terminal end to minimize bottom scour. It may also be necessary to dredge a discharge canal to direct thermal effluent into deeper water.

The thermal plume configuration of the onshore discharge produces warmer surface temperatures than the other discharge concepts because the thermal effluent receives relatively little initial dilution. Improved initial temperature reduction can be achieved by increasing the discharge velocity to enhance initial mixing of the discharge with receiving water. It is recommended that either analytical or physical hydraulic model studies be undertaken to predict the thermal plume configuration.

Special care should be taken for onshore discharge to avoid thermal recirculation to the intake structure. Some techniques available for minimizing the potential for this problem include (1) adequate physical separation of intake/discharge structures along the coastline; (2) use of riprap jetty(s) to hydraulically separate the intake and discharge; and (3) discharge via a riprap canal extending offshore.

Advantages. The primary advantage of the onshore discharge concept is that it is expected to be the least costly of the discharge systems considered. It is preferred for heat dissipation because the warm surface plume will dissipate waste heat more efficiently than if heat is mixed throughout the water column as is the case for a deep submerged discharge.

Disadvantages. There are potential disadvantages to the onshore discharge system that depend on site-specific conditions. If near-shore water depths are shallow, it may be necessary to construct a discharge canal or jetty. This may cause permanent disruption of environmentally important benthos and increase the system cost. In addition, the onshore discharge system has the greatest potential for thermal recirculation with the plant intake (particularly an onshore intake). Due to the low dilution capability of a surface discharge, mixing zone temperatures will be higher than for the submerged discharge systems. 


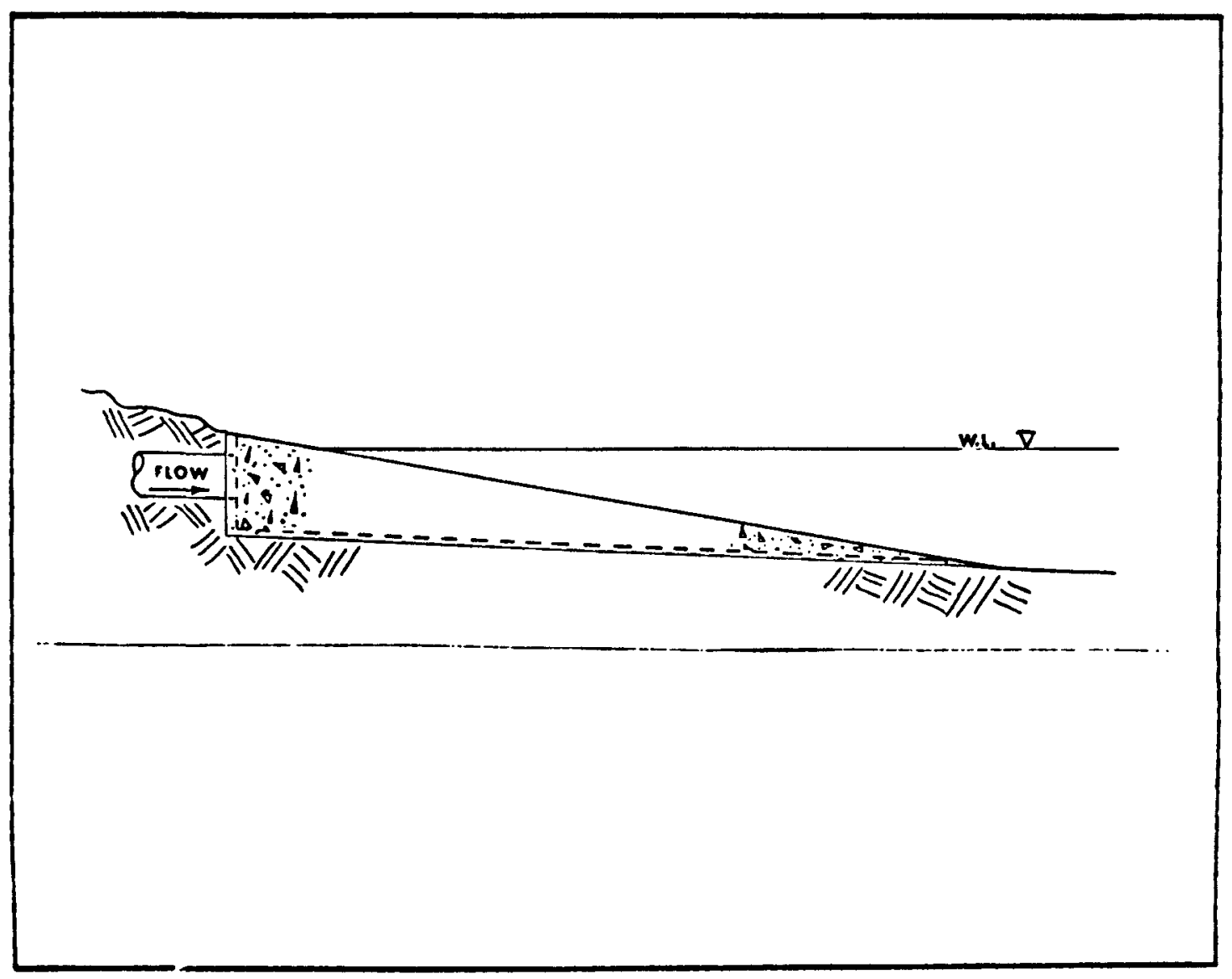

Figure 3.3. Onshore Discharge Structure. Source: U.S. Environmental Protection Agency (1977). 


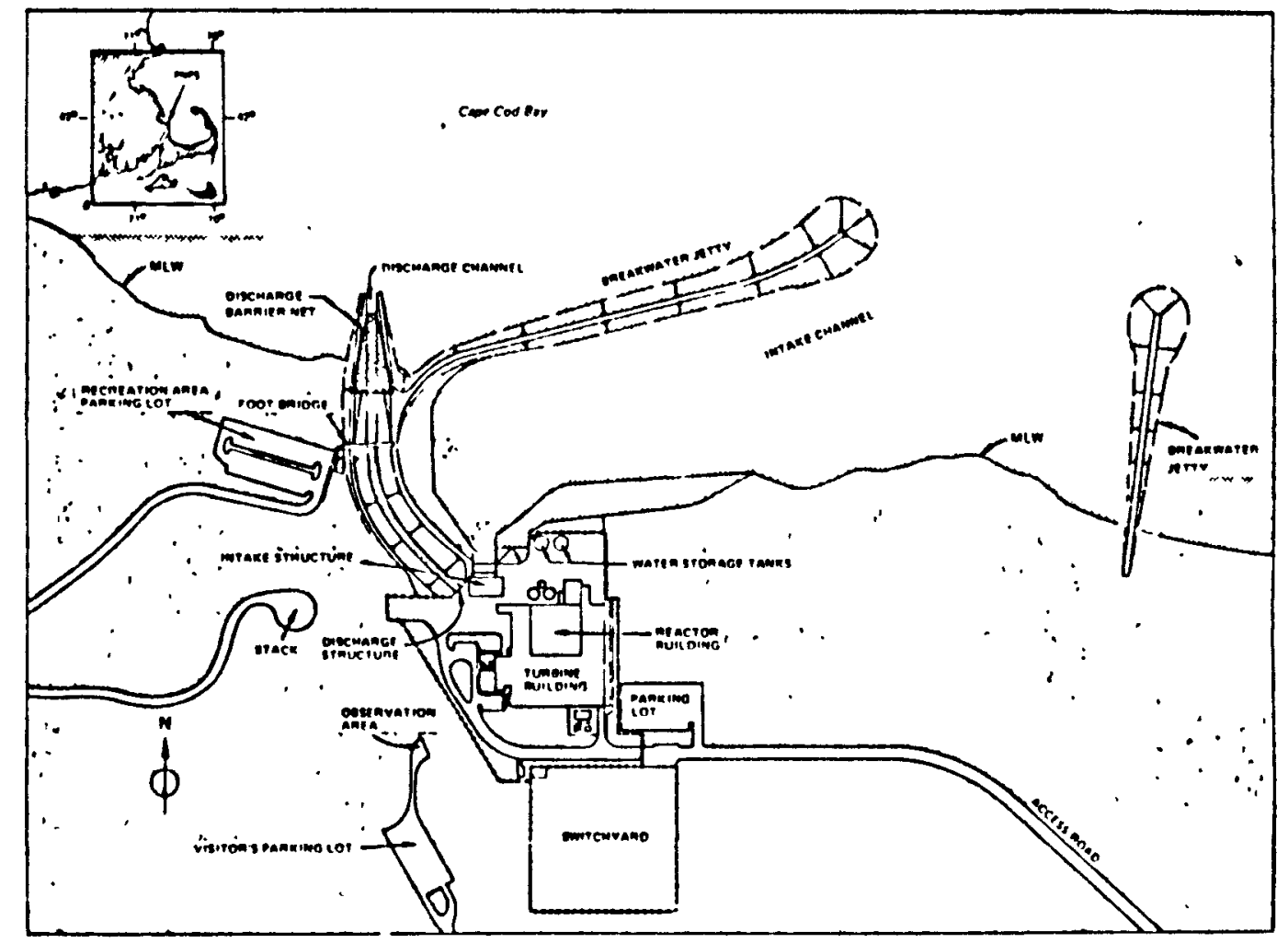

Figure 3.4. Coastal Site Layout Showing Shoreline Intake and Onshore Discharge with Discharge Channel (Pilgrim Nuclear Power Station). Source: U.S. Nuclear Regulatory Commission (1974). 


\subsubsection{Dilution Pumping Discharge System}

The dilution pumping discharge system is actually a variation of the onshore discharge. The primary difference is that the cooling water temperature is reduced by dilution prior to discharge. Additional large capacity pumps are used to reduce the cooling water temperature by adding cooler ambient water to it before discharge into the natural receiving waters. The primary reason for selecting this type of discharge system is to solve potential environmental problems associated with the thermal effluent. Figure 3.5 illustrates a dilution pumping concept.

Advantages. The only advantage of dilution pumping is that it reduces the temperature of the discharge. It does not reduce the quantity of heat discharged.

Disadvantages. Dilution pumping results in increased capital and operating costs of the discharge system. Furthermore, it increases the intake flow, which can result in greater environmental impacts. It is possible to achieve similar mixing zone temperature reduction by the use of discharge methods that do not require additional intake flow.

\subsubsection{Single-Port Offshore Submerged Discharge}

The single-port offshore submerged discharge concept consists of a single, submerged outlet pipe located offshore in deep water. Cooling water flows from the plant site to the single-port discharge via buried pipes or tunnels. The location, alignment, depth, and discharge characteristics (jet velocity) of the single-port discharge should be determined on the basis of site-specific conditions. Either analytical or physical hydrothermal studies should be undertaken to establish the final design. Figure 3.6 illustrates a typical concept for a single-port offshore submerged discharge structure. Figure 3.7 is a schematic illustration of the hydraulics of a submerged jet.

Submerged jet discharge induces rapid initial mixing of thermal effluent with receiving water. This rapid initial mixing occurs as a result of the jet discharge momentum. Rapid initial temperature reduction is achieved as the thermal effluent entrains cooler ambient water in the jet mixing region.

Offshore discharge may be required at a site where thermal recirculation or environmental concerns discourage onshore discharge. The depth and distance offshore are dependent on site factors; however, the discharge must be located in sufficiently deep water to preclude direct attack by storm waves. Furthermore, the offshore discharge should not interfere with navigation channels or boat traffic in the area. It should be clearly marked because the induced surface currents could pose a hazard to small boats or fishing activities. 


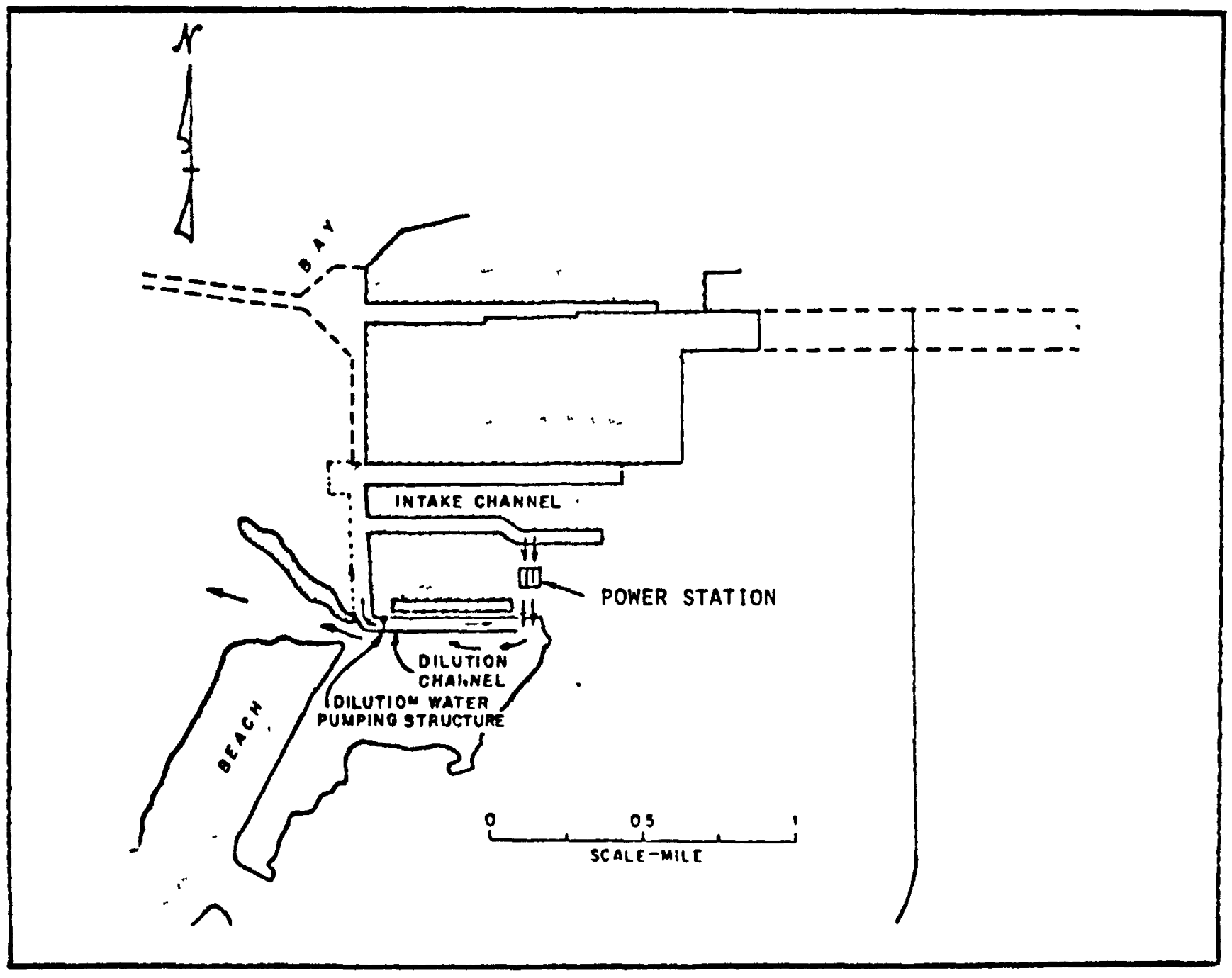

Figure 3.5. On-Site Dilution Pumping System. Source: U.S. Environmental Protection Agency (1977). 


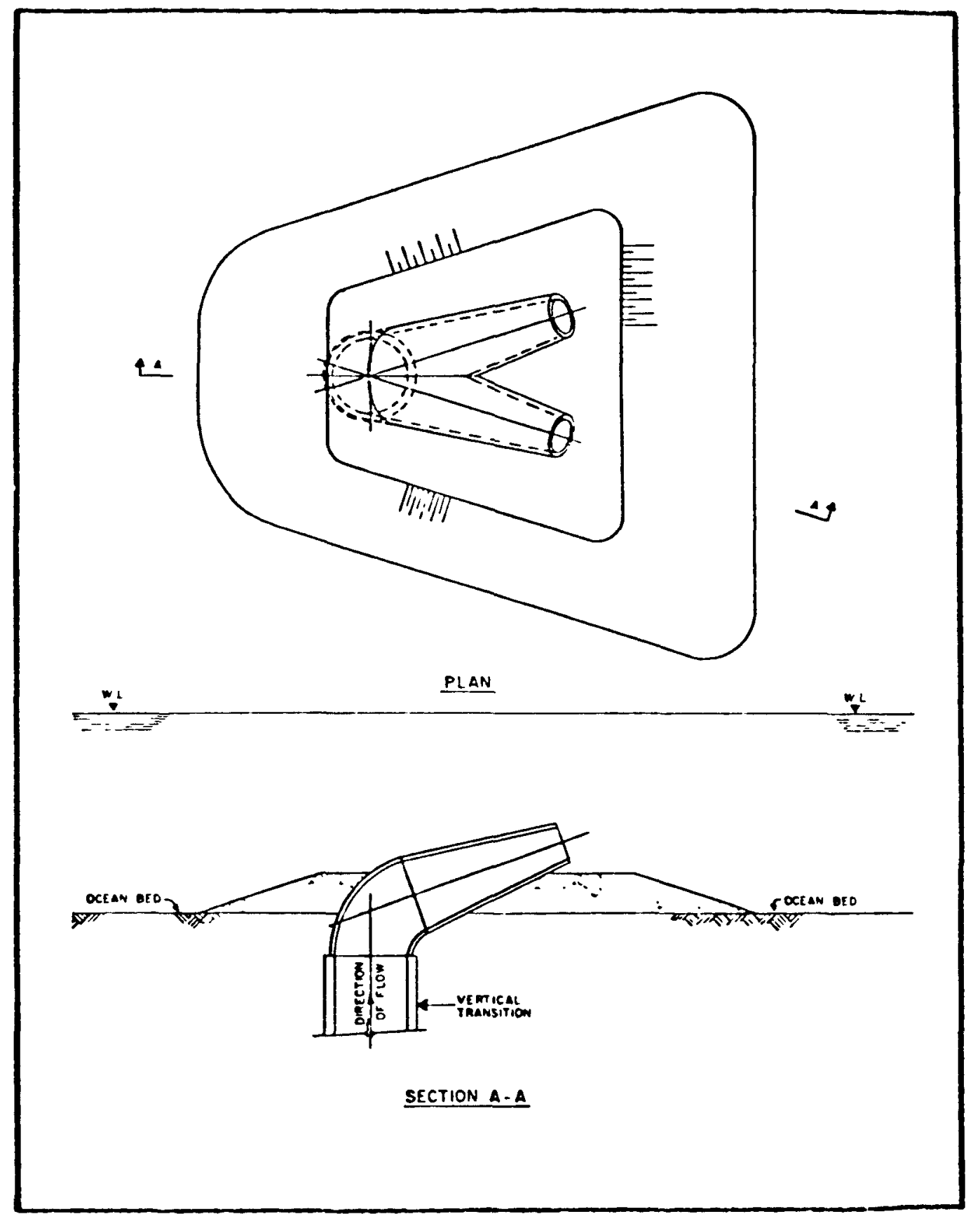

Figure 3.6. Plan and Section Views of Single Port Offshore Submerged Discharge for Two Unit Power Station. Source: Lee et al. (1977a). 


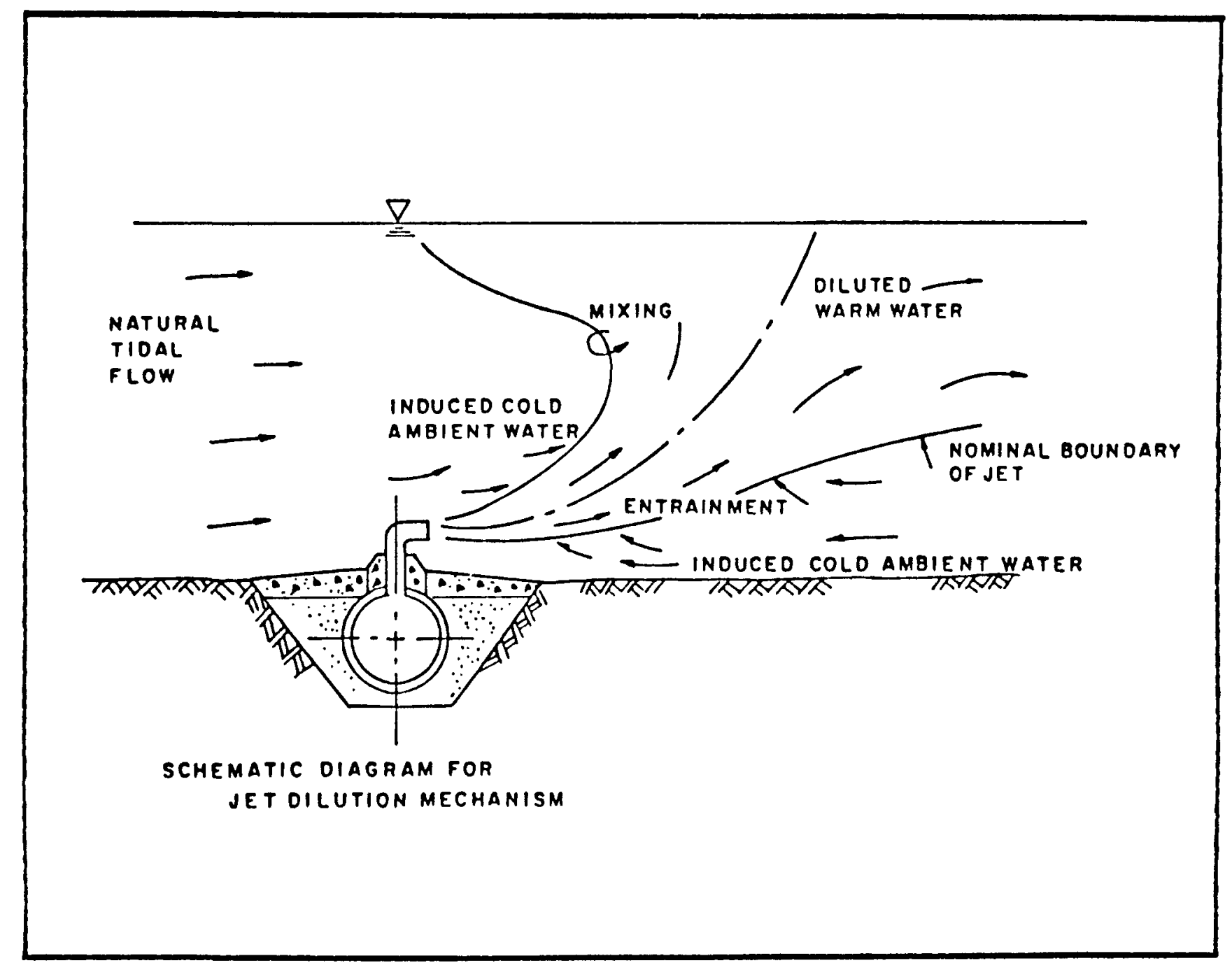

Figure 3.7. Schematic of Submerged Jet Hydraulics. Source: Lee et al. (1977a). 
Advantages. The primary advantage of this offshore discharge system compared to onshore discharge is that it will minimize the potential for thermal recirculation. This advantage is achieved by discharging offshore where the plume should be swept away, thereby avoiding the intake structure. Also, this design will result in a predominantly surface heat layer, thus allowing for a fish zone of passage under the plume in the deeper waters. The cost of this system should be less than the cost of the multiport diffuser systems.

Disadvantages. The major disadvantage of this system is its increased cost over simple onshore discharge systems. However, it may not be significantly more costly than a complete onshore discharge with long jetties. Relative to a multiport diffuser, the single-port discharge achieves higher surface maximum temperatures. This may make licensing more difficult than for a diffuser. An additional disadvantage of any offshore discharge system is that it will require installation of a buried pipe(s), which is costly and requires special construction techniques.

\subsubsection{Multiport Offshore Submerged Diffuser Discharge}

The submerged multiport diffuser discharge is basically a further development of the single-port submerged discharge. A multiport diffuser discharges offshore at depth through a series of many discharge ports. Multiport diffuser discharge enhances the dilution capability of the discharge by entraining cooler ambient water into multiple discharge jets. Rapid initial mixing and consequent temperature reduction is achieved by the jet discharge characteristics.

The location, depth, alignment, nozzle spacing, and discharge characteristics of the multiport diffuser should be determined on the basis of site-specific factors. In general, detailed hydrothermal modeling studies (analytical or physical) are required to develop the final design and predict the thermal plume configuration.

There are a variety of basic multiport diffuser types as illustrated in Figure 3.8. Each type of diffuser is particularly suited to certain local currents so the choice becomes site dependent. Figure 3.9 schematically illustrates the entrainment mechanisms of the various types of diffusers.

Advantages. The primary advantage of a submerged multiport diffuser is that it achieves substantial initial dilution and rapid temperature reduction of the thermal effluent. This is generally considered environmentally preferable and can facilitate licensing of the discharge system. Many regulatory agencies now regard submerged multiport diffuser discharge as state-of-the-art technology. 


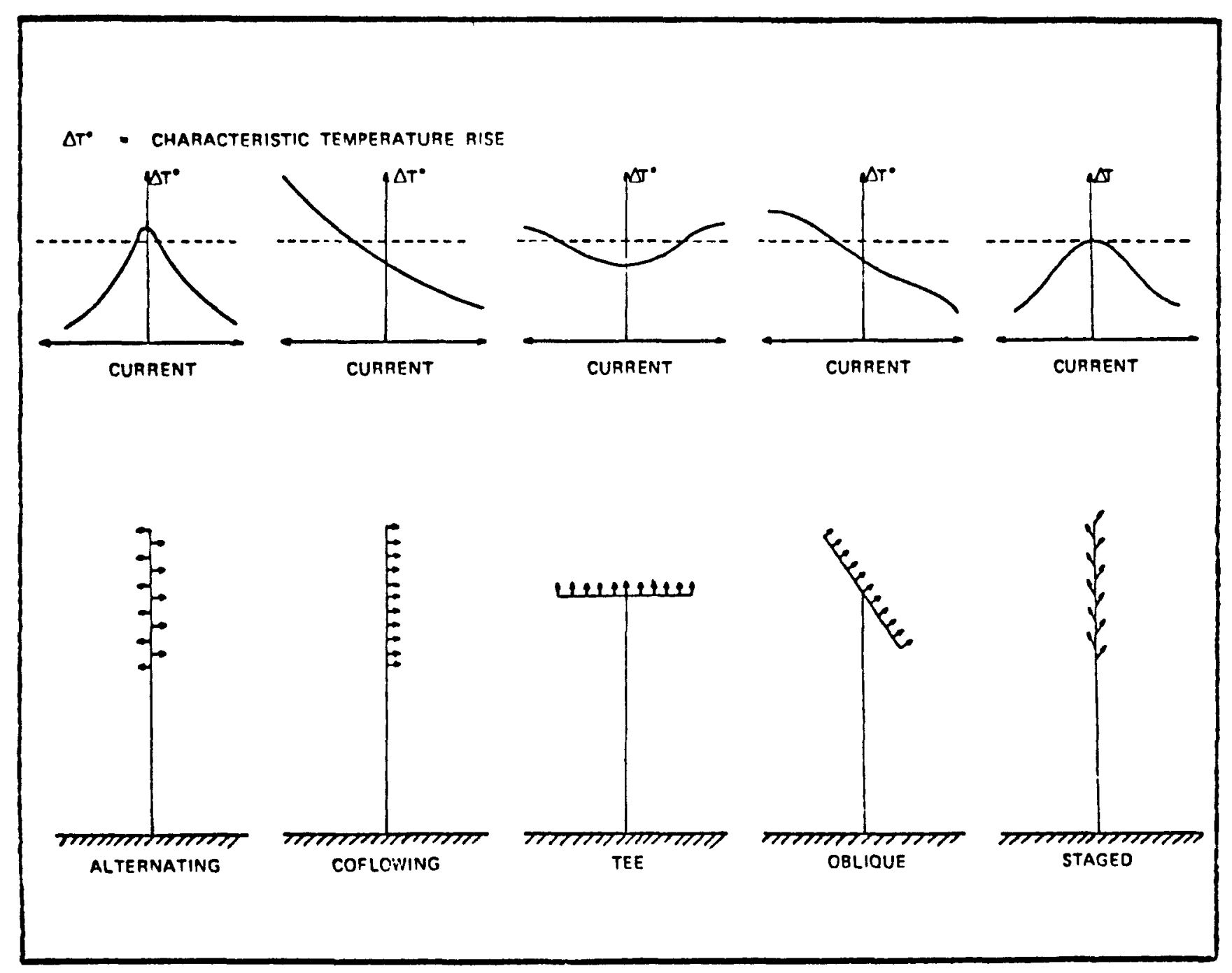

Figure 3.8. Different Diffuser Designs and Their Performance. Source: Jirka and Harleman (1973). 


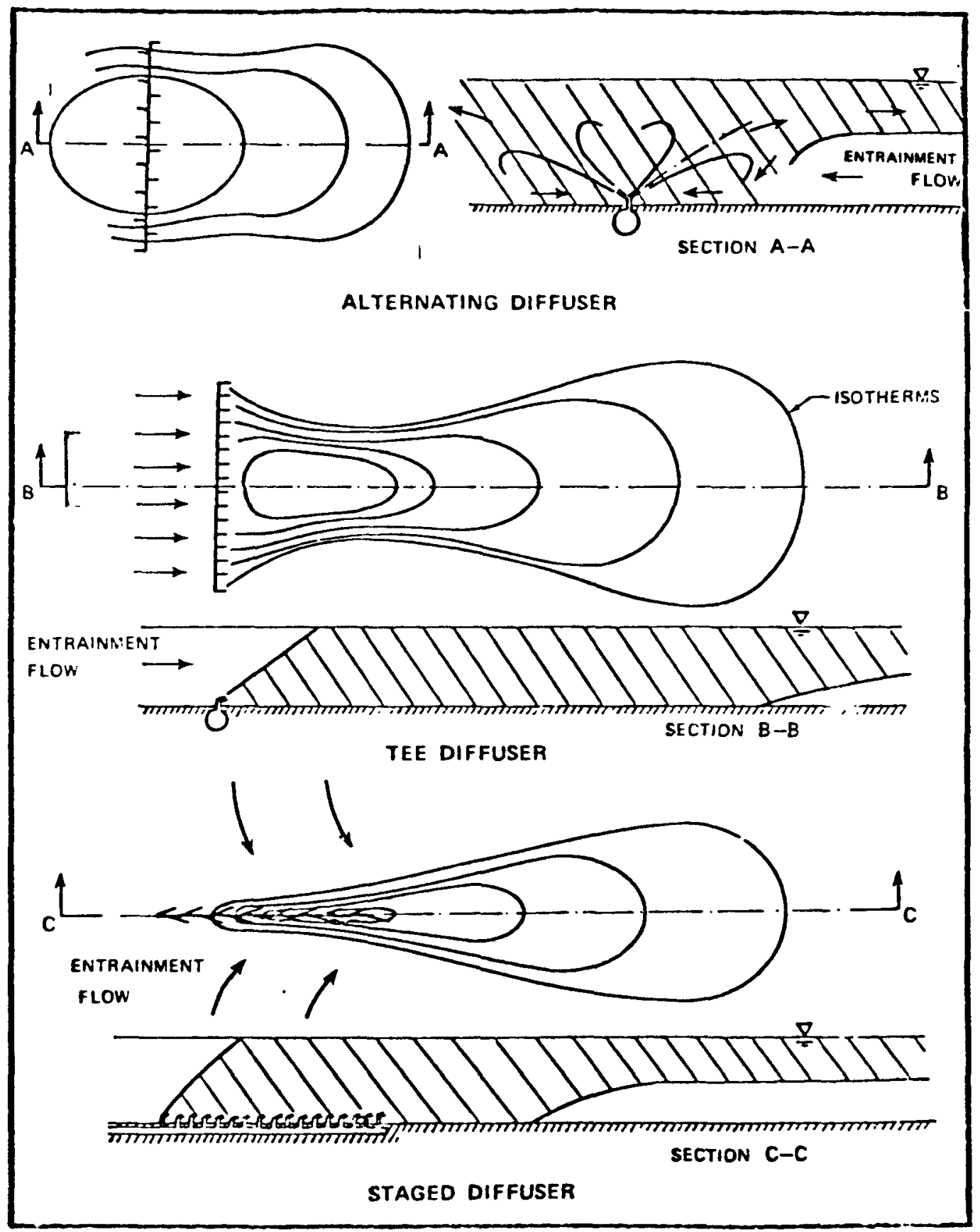

Figure 3.9. Entrainment Mechanisms and Shapes of Induced Temperature Rise Isotherms for Different Diffusers. Source: Jirka and Harleman (1973). 
Disadvantages. The multiport diffuser discharge concept is the highest-cost once-through heat rejection system. Also, installation of this system requires extensive offshore construction activities which may be subject to delay during severe weather conditions.

In addition, the diffuser discharge concept has the disadvantage that it stores heat in the water column. Strictly from a heat dissipation perspective, it is preferable to discharge a relatively hot surface plume, as is the case for the onshore surface discharge and the submerged single-port discharge. Unfortunately, regulatory agencies do not generally recognize this concept and prefer discharge systems that induce the low surface temperature increases typical of a multiport diffuser plume.

\subsection{Closed-Cycle Cooling Systems}

Conventional once-through cooling is generally preferred for optimizing the plant generating cycle efficiency. However, for some sites where water supply is inadequate or where regulatory-institutional considerations prohibit once-through cooling, it is necessary to use closed-cycle cooling. There are many types of closed-cycle cooling systems including (1) cooling ponds; (2) evaporative cooling towers; (3) spray cooling systems; and (4) dry cooling towers.

\subsubsection{Cooling Ponds}

Cooling ponds are man-made bodies of water or natural lakes used for dissipating waste heat from power plants. Heat dissipation from the pond surface is accomplished by radiation, conduction, convection, and evaporation. Since a cooling pond does not have forced air or forced water motion, it is less efficient than a cooling tower. The low rate of heat transfer requires that cooling ponds have large surface areas. The rule-of-thumb values often cited for pond surface requirements range from 4,030 to $12,080 \mathrm{~m}^{2}$ ( 1 to 3 acres) per megawatt of electric output.

For a nuclear power plant, cooling ponds are generally sized in the range of $8,060 \mathrm{~m}^{2}$ (2 acres) per megawatt. As a pond approaches the $12,080 \mathrm{~m}^{2}$ ( 3 acres) per megawatt size for a nuclear power plant, the surface water temperatures will be close to those for once-through cooling at the same site.

Cooling ponds are generally considered economically attractive for power plants sited in locations where the cost of land is low, the land is conducive to the construction of the pond, and the soil is relatively impervious. One important advantage of a cooling pond that may be incorporated in the design of the pond is its potential use for other purposes. 
Advantages. Cooling ponds have reasonable construction costs where land costs and soil conditions permit. The ponds can serve as settling basins for suspended solids, provide possible recreational areas, and be used for stocking fish species that are able to tolerate the warmer waters. Ponds can also serve as an area for aquaculture or fish farming. In addition, cooling ponds can serve as river controls to minimize flooding or increase minimum flow. They generally need very little maintenance and no makeup for extended periods. Furthermore, the ponds have a high thermal inertia, i.e., water temperature at the pond intake will not reflect short-term changes in meteorological conditions or plant loading.

Disadvantages. Cooling ponds require large land areas and preclude the use of such land for other useful purposes. They require soil basins of low permeability or liners, and they tend to concentrate dissolved solids which may leach into an underground water source. Ponds can result in fogging and icing in adjacent areas, serve as collecting areas for windblown debris, and interrupt runoff waters to former users below the pond sites.

\subsubsection{Classification of Cooling Ponds}

Cooling ponds are usually classified by depth as well as flow pattern. A pond is generally considered to be shallow if its depth is on the order of 2.4 to $6.1 \mathrm{~m}(7.9$ to $20.0 \mathrm{ft})$. Cooling ponds that exceed $6.1 \mathrm{~m}(20.0 \mathrm{ft})$ are considered to be deep ponds. Both types can be further classified according to their flow patterns.

Cooling ponds can also be classified according to their intended use as single purpose (heat rejection primarily) or multipurpose (heat rejection, recreation, irrigation, etc.). These classifications are important in the licensing procedure for power plants designed to use cooling ponds, especially in the definition of the consumptive water use of the pond.

Shallow Ponds. Shallow ponds are constructed primarily for heat dissipation. These ponds are subdivided into "flow through" or "slug flow" and "completely mixed" types. This distinction depends heavily on the pond shape and pond outlet design.

Completely mixed ponds are assumed to have a uniform temperature throughout. Conditions promoting uniform temperature are (1) a sufficient depth to allow wind-induced circulation as well as circulation induced by plant pumping, (2) a small enough depth to avoid stratification, (3) a rounded perimeter to permit the heated water to mix easily into all of the pond, (4) a discharge located away from the pond shore, and (5) a long retention time. 
Flow-through (or slug-flow) ponds are generally long and slender and have the inlet and outlet at opposite ends. They are narrow in width to minimize wind mixing, and they have a large width-to-depth ratio or low velocity to minimize vertical velocity gradients. Thus, a flow-through pond provides more rapid cooling, but it is more expensive to build than the completely mixed pond.

Deep Ponds. Deep ponds are usually constructed for multiple uses or are natural ponds that have multiple uses. Deep ponds are usually wellstratified thermally. They are further classified into three categories: (1) horizontally mixed, (2) flow-through, and (3) internally circulating. In the first two, the water temperature distribution is dominated by the natural hydrological and meteorological conditions; in the latter, the natural conditions are augmented by the design of the intake and discharge.

As the name implies, the horizontally mixed ponds exhibit uniform temperature within each horizontal plane. Reservoirs will generally approximate a horizontally mixed pond if the heat burden is less than 0.25 MWe per acre and the discharge rate to pond capacity is small. For discharges with high-flow volume outputs relative to total reservoir capacity, the pond is classified as flow-through. In this type, horizontal gradients become important.

In internally circulating ponds, the heat burden is high, and the effects of meteorological conditions are no longer dominant.

\subsubsection{Design and Sizing of Cooling Ponds}

The design of a cooling pond is affected by the local climatic, topographic, and hydrological characteristics of the site. The construction of cooling ponds is normally limited to placing dikes or low dams to take advantage of natural topography. Excavation is unrealistic for large ponds; the cost of excavating an entire pond would normally be prohibitive. Currently, the design of ponds is still very much of an art. Much more work remains to be done in defining appropriate criteria and in selecting design procedures.

Mathematical models that adequately encompass the entire range of features to describe pond performance are not available. Hence, experience and simplified analysis provide the primary basis for the engineering design of cooling ponds. The most simplified models are the completely mixed flow model and the slug flow model. These two flow models, combined with empirical correlations for surface heat exchange coefficient and equilibrium temperature, give a rough estimate of the pond size required to reject a given heat load. 


\subsubsection{Evaporative Cooling Tower Systems}

In an evaporative or wet cooling tower, most of the waste heat is dissipated to the atmosphere by evaporation of a small portion of the circulating cooling water. Heated water from the plant condenser is pumped to the top of the tower's fill or packing material. The water then flows or splashes down through the fill to the water collecting basin while air sweeps through the fill area. As the water and air come in contact, a small portion of the water becomes vaporized, thus carrying with it the latent heat of evaporation. In the process, air is humidified and the remaining unvaporized water is cooled. The water falls by gravity through the fill whereas the air flows either perpendicular to the flow of water (crossflow) or upward and parallel to the flow of water (counterflow).

Three different methods are used to provide a continuous flow of fresh air through the tower, resulting in three major tower types, as described below.

Mechanical Draft Cooling Towers. A mechanical draft cooling tower is one that uses a fan to move the air through the tower. The fan provides a constant volume of air flow through the tower, independent of the ambient weather conditions. The fans can be either induced-draft or forced-draft fans, depending on whether the air is pulled or forced through the tower. For power plant application, most mechanical draft towers use induced-draft fans. Air flow through the tower is varied by changing the fan motor speed and/or the pitch of fan blades. Figure 3.10 shows typical mechanical draft towers of the counterflow and crossflow types.

Natural Draft Cooling Towers. A natural draft tower is one that depends on a chimney or stack to induce air movement through the tower. Instead of a constant volume of air flowing through the tower, as in a mechanical draft tower, the natural draft tower has an air flow rate that is proportional to the density difference between the ambient air and the warmer humid air in the tower. Figure 3.10 shows typical counterflow and crossflow natural draft cooling towers.

Fan-Assisted Natural Draft Cooling Towers. A fan-assisted natural draft cooling tower is one that depends on both the chimney effect and fans to move the ambient air through the tower. The fans are usually located around the periphery at the base of the tower. The fans augment the natural draft and provide a nearly constant volume flow. In addition, the air flow provided by the fans allows a substantial reduction of the tower height needed to provide the air flow through natural draft. 


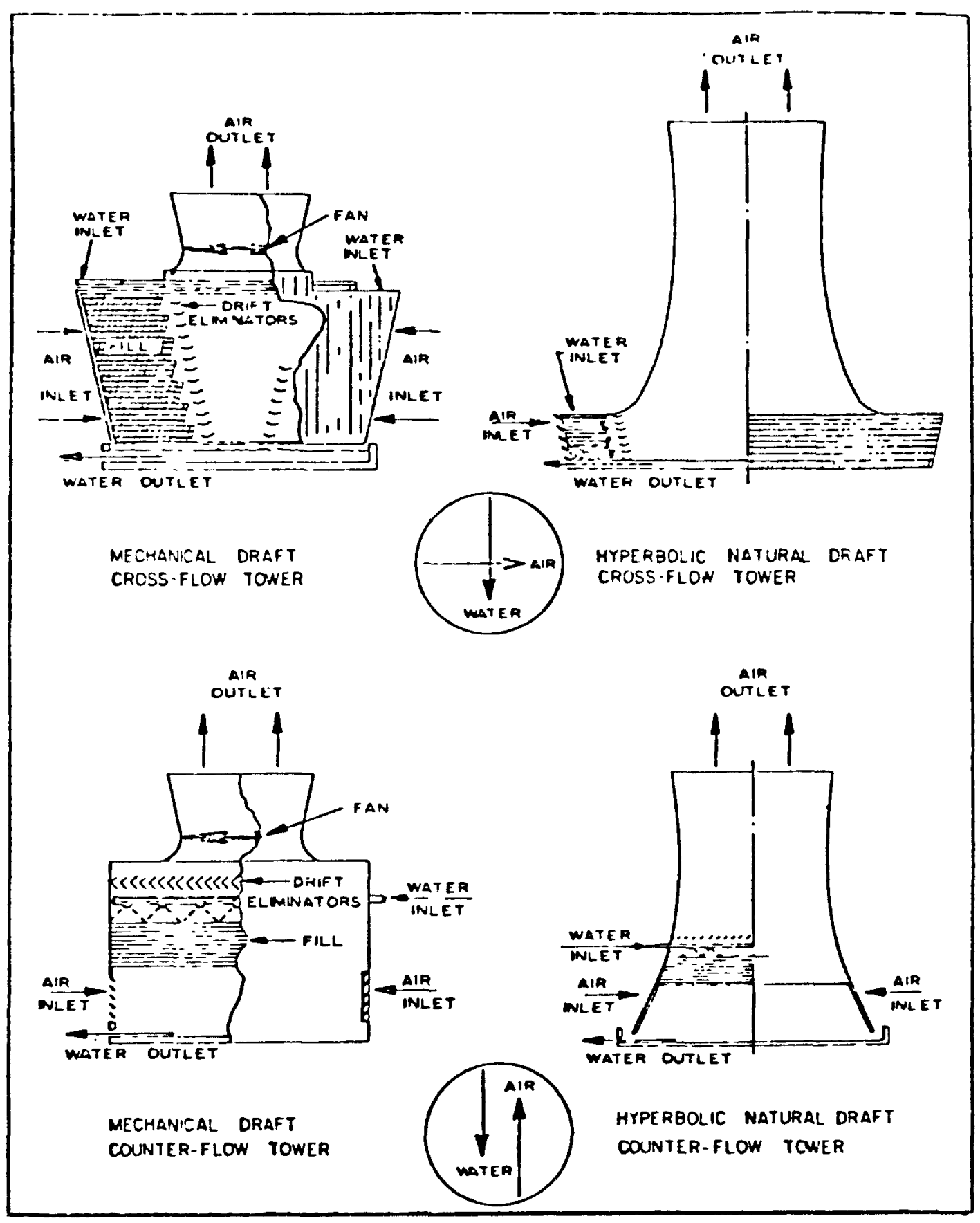

Figure 3.10. Four Basic Types of Cooling Towers. Source: U.S. Environmental Protection Agency (1979). 


\subsubsection{Design and Performance Parameters}

The major parameters that influence the size and performance of a cooling tower are (1) cooling range, (2) approach, (3) ambient wet bulb temperature, (4) flow rate of water to be cooled, (5) flow rate of air passing through the tower packing, (6) performance coefficient of the tower packing, and (7) volume of the tower packing. The parameters over which the cooling system user has control are the cooling range, the approach, and the design wet bulb.

The ambient wet bulb temperature is an important factor in designing, sizing, and selecting evaporative towers. It is a controlling factor because it is the lowest temperature to which water can be cooled by the evaporative method. Selection of a proper design wet bulb temperature is, therefore, vital in determining the optimum cooling tower size. A design wet bulb temperature that is too high can result in an oversized tower; one that is too low can result in inadequate tower capacity, such that the power plant it serves would experience severe capacity deficits at high ambient temperatures. Current practice is to select a wet bulb temperature that is exceeded no more than one percent of the time during an annual cycle.

Once the design wet bulb temperature is established, the range and approach determine the size and, consequently, the cost of the cooling equipment. Thus, in economic evaluations of wet tower cooling systems, these variables are extensively investigated for each application. The heat rejection duty of the tower is equal to the product of the range, circulating water mass flow rate, and specific heat of water. The increased capital cost for a larger tower would be compensated by better operating performance in that the lower range of this tower would achieve a lower back pressure in the turbine and, consequently, lower operating penalties over the lifetime of the plant.

The final and most important temperature consideration is establishment of the approach, the difference between the cold water temperature and the wet bulb temperature. Once the design wet bulb temperature and range have been determined, the approach fixes the operating temperature.

With a given heat load, the size of the cooling tower required increases as the approach decreases. Of all of the variables involved, the approach can have the greatest effect upon the size and cost of the cooling tower. The closer the cold water temperature approaches the wet bulb temperature, the greater the increase in cooling tower size. For example, consider a tower designed for a $15^{\circ} \mathrm{F}\left(8.4^{\circ} \mathrm{C}\right)$ range and $15^{\circ} \mathrm{F}$ $\left(8.4^{\circ} \mathrm{C}\right)$ approach to a $76^{\circ} \mathrm{F}\left(24^{\circ} \mathrm{C}\right)$ wet bulb temperature. Decreasing the approach to $10^{\circ} \mathrm{F}\left(5.5^{\circ} \mathrm{C}\right)$ will increase the tower size by 50 percent. In 
comparison, decreasing the range from $15^{\circ} \mathrm{F}\left(8.4^{\circ} \mathrm{C}\right)$ to $10^{\circ} \mathrm{F}\left(5.5^{\circ} \mathrm{C}\right)$ will increase the tower size by only 15 percent.

As in the example described in the discussion on range, increased capital costs for larger size cooling towers are compensated for by better operating performance. In evaluating the costs of cooling systems, the investigation should include the trade-off between the capital costs and the operating costs of each design.

\subsubsection{Makeup Requirements}

In evaluating the feasibility of a site for cooling towers, makeup water supply must be considered. Makeup water is required to accommodate cooling tower water loses due to evaporation, drift, and blowdown. Evaporative water loses are incurred in the process of transferring heat from water to air by evaporation. This is a function of the amount of heat to be rejected. Blowdown is required to limit the concentration of dissolved solids in the circulating water. This varies according to the water quality of the makeup water supply. At low concentrations it is similar to the evaporative losses, but at higher concentrations it can be significantly reduced. Drift losses occur when water droplets are carried out of the cooling tower with the exhaust air stream. In general, the drift rate of conventional cooling tower designs varies from 0.005 to 0.02 percent of circulating water flow.

\subsubsection{Spray Cooling Systems}

The spray ponds or canals are extensions of cooling ponds and cooling tower technologies. Cooling is obtained primarily by spraying water from a pond or canal into the ambient air, whereby water is evaporated to effect cooling of the water. The purpose of spraying the water is to increase the water-to-air contact area. The result is a significantly increased heat transfer rate per unit area of pond surface. Thus, the land requirements for spray systems are reduced considerably as compared to those of simple pond systems.

The spray system can be designed as a fixed-pipe pond configuration called a spray pond or as a floating-module canal system called a spray canal. Spray ponds are generally used for small heat rejection requirements, such as the ultimate heat sink for nuclear power stations, whereas spray canals are generally used for power plant waste heat rejection.

The floating spray system can use any one of a number of different, commercially available modules. The spray modules are anchored in the discharge canal or pond. Each module is complete with a float-mounted pump and spray heads. One such module is shown in Figure 3.11. The 

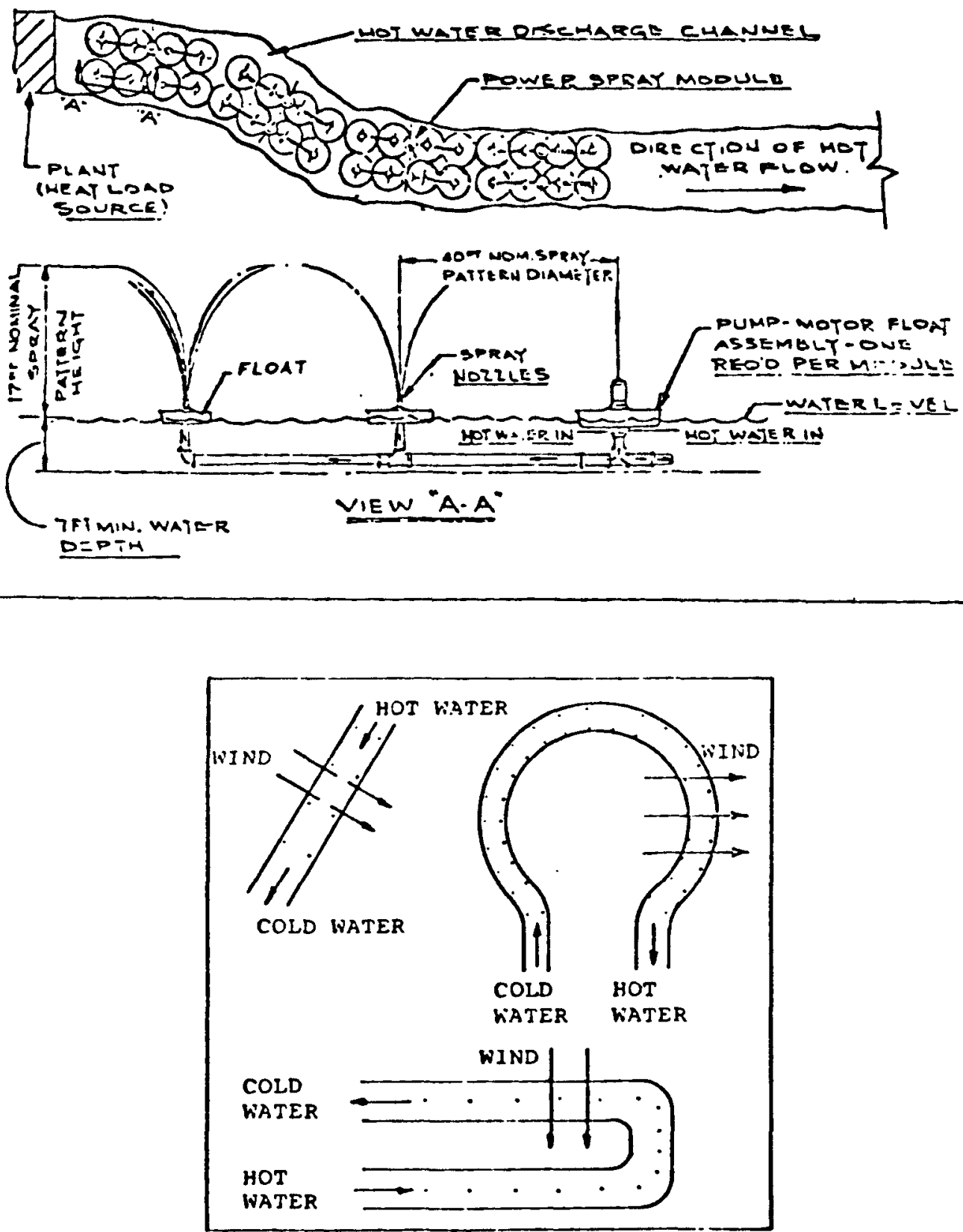

Figure 3.11. Typical Ceramic Powered Spray Module Canal Cooling System. Source: U.S. Environmental Protection Agency (1979). 
module consists of four spray nozzles mounted on a 36.6-m (120-foot) length of pipe. The entire assembly floats in the water with the spray nozzles above the water surface. The modules are equipped with a 75-horsepower motor and a 10,000-gpm pump. Modules are placed in a canal with the axis of each module parallel to the streamflow, as shown in Figure 3.11.

Spray canal cooling is a relatively new cooling concept that is currently in use at a small number of power plants. The performance and cost of the spray systems are competitive with wet cooling towers. The possibility of using them, however, will depend on the availability of land and the cost at the site because the construction of the canal is one of the major cost components.

The design parameters to be considered in sizing spray canal systems for a specific heat load using standard modules are (1) cooling range and water flow rate, (2) approach to the wet bulb temperature, (3) ambient conditions (dry and wet bulb temperatures, wind speed, and wind direction), and (4) number of modules per pass.

The wet bulb temperature, cooling range, and approach affect the canal performance in a manner similar to that for wet cooling towers. The extent to which ambient wind conditions affect a spray system's performance depends on the volume of air passing through the spray region. High wind speeds permit more efficient heat transfer to the atmosphere, whereas low wind speeds hinder effective interaction of the spray and ambient air.

For optimum thermal performance, a spray system canal should be placed perpendicular to the prevailing summer or design wind direction. A long, narrow canal that minimizes recirculation will perform better than a wide canal with many spray module units in the pass. Figure 3.11 shows three possible canal arrangements for spray cooling systems. Figure 3.12 shows design curves for sizing spray canal systems.

\subsubsection{Dry Cooling Tower Systems}

Dry cooling towers are considered for a site only if the water supply is inadequate for makeup to wet evaporative closed-cycle cooling systems. For large nuclear units, dry cooling technology is not generally considered state-of-the-art. In a site-selection study, it is generally recommended that alternative sites with adequate water supply be thoroughly considered before selecting a site requiring dry cooling towers. 


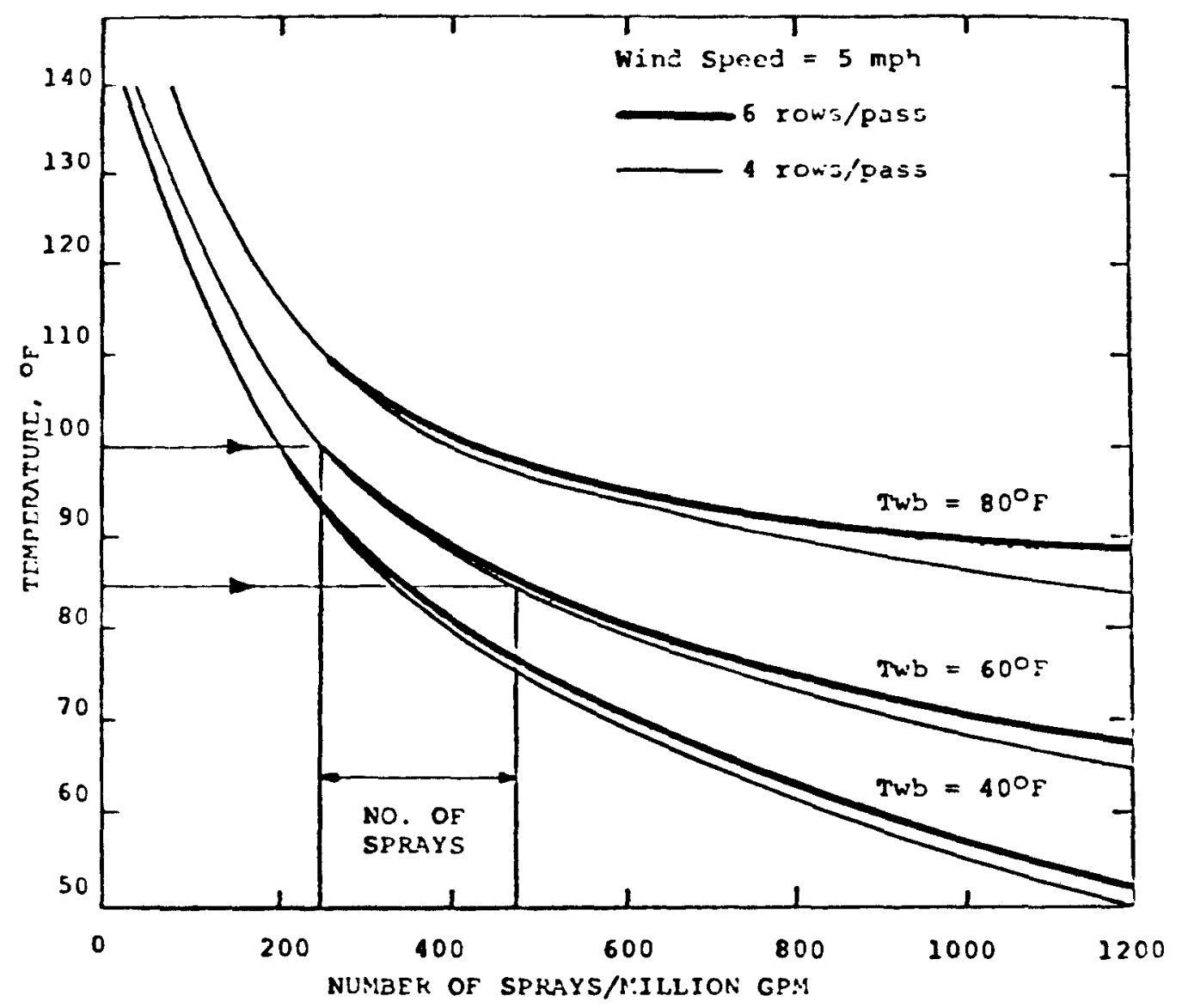

Figure 3.12. Design Curves for Sizing Spray Canal Systems. Source: U.S. Environmental Protection Agency (1979). 
Dry cooling towers generally employ finned-tube heat exchangers to reject heat by circulating water inside the tubes and by passing the atmospheric air over the outside tubes and fin surfaces. In contrast to the wet cooling systems previously described, the heat transfer mechanism is convective heat transfer rather than heat and mass transfer between the water being cooled and the cooling air. The absence of evaporative heat exchange eliminates the makeup water requirement and the formation of vapor plumes that constitute the major disadvantages of wet cooling systems.

Dry towers can be of the mechanical draft or natural draft type. In a mechanical draft tower, ambient air is induced or forced by fans to pass over the heat transfer surface. In mechanical draft towers, air flow is controlled by using either variable fan speeds or variable pitch blades. The natural draft tower depends on the air density difference in the atmosphere and in the tower to produce the buoyancy force for inducing the air flow. The air flow rate can be controlled by the use of louvers or dampers.

Various studies have indicated that dry tower cooling systems have both high capital cost and severe operating penalties. The high capital cost results from the need for an extensive finned-tube heat exchanger surface; the operating penalties result from the high condensing temperatures experienced during peak ambient conditions. Because of the high capital and operating costs, dry tower systems are not widely used in the power industry at the present time. Only a relatively small number of existing or new power plants are currently employing dry cooling systems. The largest of these units are the 360 MWe Schmehausen power station in West Germany and the 300-MWe Wyodak power station in the United States. Both are fossil-fired units.

\subsubsection{Potential for Using Seawater Closed-Cycle Cooling Systems}

A survey has been conducted to determine if any seawater closedcycle cooling system is now operating at a power generating facility typical of the size currently being constructed or planned by the utility industry (Utility Water Act Group 1978a). The survey results indicate that there is one operating seawater closed-cycle cooling system at a small peaking plant ( $96 \mathrm{MWe}$ ) in Fleetwood, England. The circulating water flow does not approach that of a new 1,000-MWe fossil or nuclear plant.

There are 10 operating brackish water systems serving coastal power plants in the United States today. These plants, however, are either much smaller than typical units now being constructed or planned, or the intake salinities are significantly lower than those typical of seawater, which may range from 28,000 to 37,000 parts per million (ppm) salinity. 
Another study has investigated the engineering considerations in building and operating full-scale seawater towers, the environmental side effects of such towers, and the increased cost of construction and operation created by those factors (Utility Water Act Group 1978b). The study considers cooling tower materials problems due to use of brackish water and notes that they may be aggravated by seawater use. Nine of the ten United States coastal power plants and both English power plants using seawater closed-cycle cooling systems reported materials problems due to use of salt water. The study also reviewed operating problems due to saltwater towers and reports that arcing or station outages occurred at seven of the ten United States power plants using saltwater of cooling systems. Corrosion in the tower area was reported by two of the remaining three United States plants.

Environmental side-effects include the effects of salt drift from the towers. The salt drift from full-scale seawater towers may well exceed air quality limitations on particulate emissions. It is calculated that a seawater cooling tower (at a concentration factor of 2.0 and a drift rate of 0.002 ) serving only a 100 MWe nuclear unit would emit more than 30 pounds of particulates per hour, the emission limit set by the state of New Jersey. A seawater natural draft tower serving a large 1,150-MWe nuclear unit would emit over 400 pounds of salt per hour. Emissions of particulate matter from new cooling towers may conflict with other air quality planning and regulatory requirements. In addition, seawater towers may conflict with coastal zone and land-use planning objectives or have undesirable aesthetic impacts.

Finally, the increased costs of constructing and operating seawater towers must be considered. The Utility Water Act Group (1978b) study estimates that the capital cost of seawater towers is approximately 25 percent higher than the capital cost of freshwater towers. In addition, seawater towers incur higher capability and energy penalties, up to 5.9 and 7.0 percent, respectively.

It is concluded that seawater closed-cycle cooling is not practical or desirable at this time. If a coastal site is determined to be unsuitable for open-cycle cooling for any reason (e.g., water supply, regulatory requirements, institutional issues, ecological impacts), it is recommended that freshwater closed-cycle cooling be used or the site be judged not feasible for a large nuclear generating unit.

\subsection{COOLING SYSTEM FLOW AND TEMPERATURE RISE}

Consideration of cooling system flow and condenser temperature rise should be made early in the feasibility and conceptual design assessment of a site. Although the heat rejection requirements of the plant are essentially constant, the designer must select the flow and temperature 
rise. The designer has the option of selecting a high cooling system flow with low condenser temperature rise or a lower flow with corresponding higher temperature rise.

Table 3.1 shows some typical combinations of flow and temperature rise for a 1,000-MWe plant operating at an assumed plant heat rate of $10,500 \mathrm{Btu} / \mathrm{kWh}$. Figure 3.13 illustrates the relationship of cooling water flow, condenser temperature rise, and efficiency for typical generating units.

Table 3.1. Estimated Cooling Water Requirements for a 1,000-MWe Nuclear Plant Operating at Full Load

(Assumed Heat Rate $=10,500 \mathrm{Btu} / \mathrm{kWh}$ )

\begin{tabular}{|c|c|c|c|}
\hline \multicolumn{2}{|c|}{$\begin{array}{c}\text { Condenser } \\
\text { Temperature Rise }\end{array}$} & \multicolumn{2}{|c|}{ Condenser Flows } \\
\hline${ }^{\circ} \mathrm{F}$ & ${ }^{\circ} \mathrm{C}$ & $\begin{array}{l}\text { Cubic feet/ } \\
\text { second }\end{array}$ & $\begin{array}{l}\text { Liters/ } \\
\text { second }\end{array}$ \\
\hline 10 & 5.5 & 2,920 & 82,700 \\
\hline 15 & 8.3 & 1,950 & 55,200 \\
\hline 20 & 11.1 & 1,460 & 41,350 \\
\hline 30 & 16.6 & 975 & 27,600 \\
\hline 40 & 22.2 & 730 & 20,670 \\
\hline
\end{tabular}

The selection of a cooling system temperature $\mathrm{rise} /$ flow combination for a particular site is based on engineering, economic, environmental and regulatory considerations. For example, if the site requires long intake and discharge cooling water lines, the cost of the cooling system can be substantial and there is a strong economic incentive to minimize the pumping capacity and size of system components. This can be done with the high condenser temperature rise/low flow cooling system option. These economic advantages in the capital and operating costs of a cooling system at such a site may offset the slight reduction in plant generating efficiency incurred at higher condenser temperature rises.

Regulatory requirements and institutional pressures can also affect cooling system design. In recent years there has been concern to minimize the quantity of water pumped through power plant cooling systems. This can be accomplished with the high temperature rise/low 
COOLING WATER REQUIREMENTS FOR

FOSSIL AND NUCLEAR POWER PLANTS

-. NUCLEAR,

$\eta_{1}=33 \%$,

IN-PLANT LOSSES

$=5 \%$
FOSSIL,

$\eta_{1}=40 \%$

IN-PLANT AND

STACK LOSSES

$=15 \%$

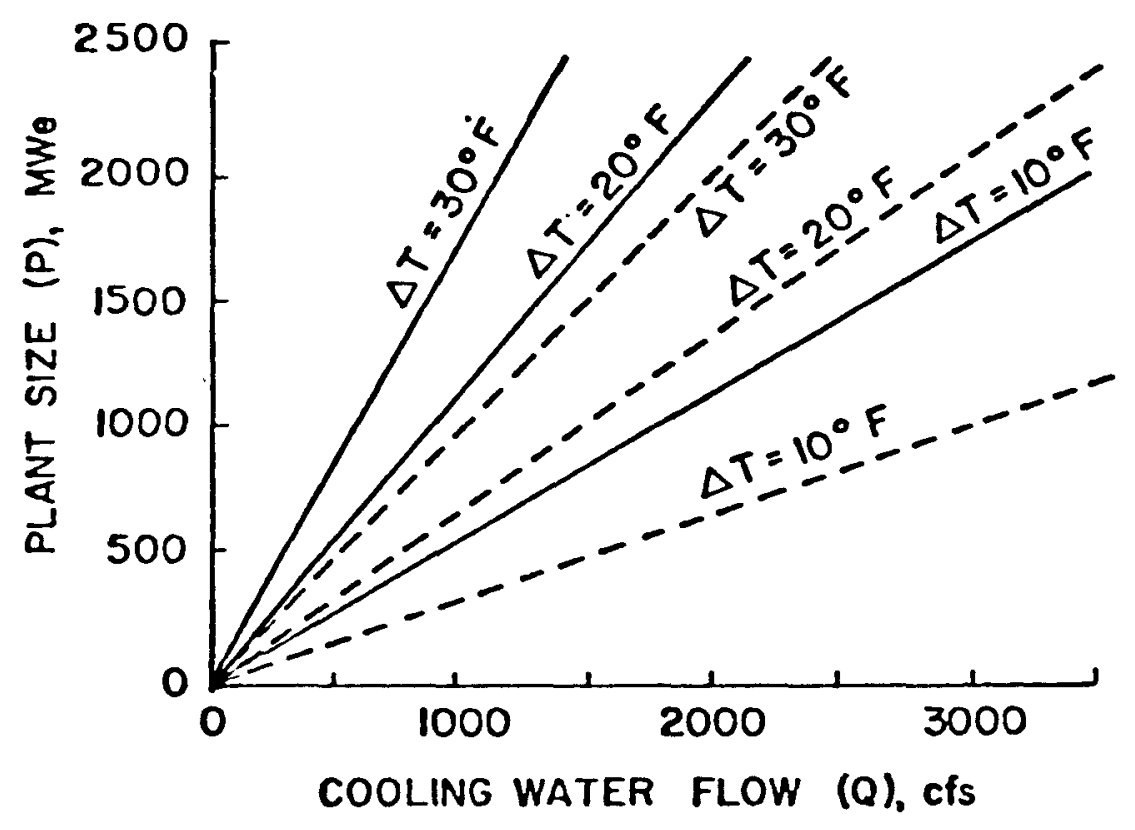

$\triangle T=$ CONDENSER TEMP. RISE

$\eta_{1}=$ PLANT THERMAL EFFICIENCY

Figure 3.13. Cooling Water Requirements as a Function of Plant Size, Condenser Temperature Rise and Thermal Efficiency.

Source: U.S. Environmental Protection Agency (1977). 
flow cooling system option. The high effluent temperatures of such a system can be effectively cooled by the use of submerged multiport diffuser discharge.

Environmental concerns at a site may also influence the selection of cooling system temperature $r$ ise and flow. For example, if cooling water is to be withdrawn from ecologically important waters, minimizing the quantity of cooling water flow is advantageous.

The highest known cooling water temperature rise for a large nuclear power plant is $39^{\circ} \mathrm{F}\left(21.6^{\circ} \mathrm{C}\right)$. This is for the Seabrook Station which has a condenser cooling flow of 24,600 liters/second $(390,000 \mathrm{gpm})$ per 1,150-MWe generating unit (Public Service Company of New Hampshire 1973).

\section{ENVIRONMENTAL IMPACTS OF COOLING SYSTEMS}

\subsection{DESCRIPTION OF IMPACTS}

\subsubsection{Impacts of Once-Through Cooling Systems}

Within the 48 coterminous states of the United States, approximately $30 \%$ of the mean annual runoff is withdrawn by man from natural water bodies for industrial, commercial, agricultural, and municipal use. About one-third of this usage is for steam-electric power plant cooling, amounting to an average rate of withdrawal of fresh water for cooling water purposes in 1974 of $5,623 \mathrm{~m}^{3} / \mathrm{s}$ (equivalent to about $11 \%$ of the mean annual runoff). All but about $2 \%$ of this water is returned to the natural waterway (after accounting for increased evaporation rates due to elevated temperatures). However, because electric power generation does account for the temporary diversion of a significant portion of the annual runoff, the potential for a considerable impact on the environment exists. The potential impact can be divided into three categories: (1) the direct impact of drawing organisms into the intake, trapping some of them on the screens (impingement and entrapment), and sending some of them through the pump and condensers (entrainment) back into the water body, (2) the impact on organisms that are entrained into the heated plume without having passed through the plant, and (3) the impact of the increased average temperature of a local region of the water body.

\subsubsection{The Effects of Passage through the Power Plant}

The physical withdrawal of large quantities of water from a natural water body can present a problem in itself. Large $f i s h$ may avoid the intake, but small fish and other free-swimming species can be drawn into the intake, trapped by the screens (impingement), and either directed 
back to the water body or more often destroyed. Smaller organisms -including plankton, fish eggs, and fish larvae -- pass through the screens (entrainment) and through the condenser cooling system. These organisms may undergo mechanical damage in the pumps and condenser due to abrasion and pressure changes, thermal shock in the condenser, and chemical shock due to the presence of biocides, other water treatment chemicals, or corrosion products. The damage may not be lethal but may affect an organism's ability to survive once it is returned to the water body. In closed-cycle systems, all the organisms drawn into the intake are destroyed because the water is not returned directly to the natural water body. However, flow rates for closed-cycle systems are much smaller than those for once-through systems because only makeup is required and fewer numbers of organisms are likely to be drawn into the system.

\subsubsection{The Effects of Passage through the Thermal Plume}

Organisms can come to live in or pass through the thermal plume in any of several ways. They can pass through the intake and power plant; they can be carried along with the dilution water entrained into the thermal plume in the mixing process; they can be attracted to the warm water, especially during winter months; or they can be sedentary and exist naturally in the region that happens to be occupied by the thermal plume. The effects of living in or passing through the thermal plume are estimated to be far less serious than the effects of passing through the power plant itself. The seriousness of the effect depends on the type of organism, the duration of the exposure, and the temperature elevation encountered. Indeed, the thermal effect can work both ways. Fish that choose to live in the plume may become acclimated to the elevated temperature and upon plant shutdown may undergo deleterious thermal shock. In the case of a narrow waterway, such as a river or estuary, the heated plume may serve to block the passage of anadromous species and therefore inhibit their reproductive cycles.

\subsubsection{The Effects of Regional Warming}

Temperature plays a major role in regulating the life cycles of aquatic organisms. Activity, feeding, growth, and reproduction are affected by temperature. Secondary effects, such as increased bioaccumulation of toxic materials, can also occur. Any change in the normal thermal cycle of a water body may affect the character and species diversity of organisms living there. The growth of nuisance organisms, such as certain types of algae, may be enhanced with increased temperature, whereas reproduction of certain cold-water fish can be significantly reduced by elevated temperatures. The effects of regional 
warming clearly depend on the size and natural characteristics of the water body. Large lakes and open marine coastal waters are flushed by natural currents and tides, whereas small lakes and rivers with low flows may show notable, persistent temperature alterations.

This brief summary of the types of potential detrimental environmental effects due to once-through cooling systems is of course restrictive. The magnitude of and, indeed, the presence of the impacts vary from site to site. The assessments of ecosystem impacts (e.g., intake impingement effects on aquatic populations) and of mitigative strategies (e.g., fish screens) are themselves often moot issues and the subject of research. It should be noted, however, that the environmental acceptability of once-through cooling systems at specific sites may well hinge on site-specific ecosystem impacts.

\subsubsection{Impacts of Closed-Cycle Cooling Systems}

closed-cycle cooling systems have the potential for reducing the environmental impacts of once-through cooling systems. However, there are unique environmental impacts associated with closed-cycle cooling systems that must be considered in the site-selection process.

This section provides background information on the potential environmental impacts resulting from the operation of closed-cycle cooling systems. Environmental impacts of closed-cycle cooling systems can be divided into three broad categories: (1) hydrological and aquatic impacts, (2) atmospheric and terrestrial impacts, and (3) land-use, aesthetic, and noise impacts.

\subsubsection{Hydrological and Aquatic Impacts}

Hydrological and aquatic impacts are those effects caused by the makeup water intake structure itself, effects due to water consumption, and effects created by the cooling tower blowdown. Makeup water intake structures may entrain organisms that lack sufficient mobility to withstand the pumping forces. These organisms may impinge on the intake screens intended to prevent the entry of debris with the water supply. As a result, not only will these organisms be damaged or destroyed, but operating efficiencies of the closed-cycle cooling system may be reduced.

Most water consumed by a closed-cycle cooling system is lost via evaporation. Evaporative losses place a renewal burden on the water body from which the supply is drawn. This constitutes a depletion of resources if the water body is incapable of replenishing the supply in quality and quantity. 
Blowdown water has a relatively high temperature and a relatively high concentration of total dissolved solids. Depending on the amount of water and the nature of the receiving water body, cooling water blowdown can cause detrimental effects. For example, the ecology of the receiving body of water may be damaged and the overall water quality may be lowered because excessive chemical or heat loading may affect the biota and alter the ecology in the area where these waters are being discharged.

\subsubsection{Atmospheric and Terrestrial Impacts}

Atmospheric and terrestrial impacts are those effects caused by the discharge of large quantities of warm, humid air into the atmosphere, as well as effects on biota due to the entrained impurities in the discharged vapor. Although airborne heat and water vapor emitted from closed-cycle cooling systems are not classified as pollutants, large amounts of water vapor are released to the atmosphere by these systems. Once released to the atmosphere, the excess vapor cools and may form local fog or ice conditions in the winter and may lead to increased precipitation. If the emitted water vapor mingles with a nearby industrial stack plume containing a reactive substance such as sulfur dioxide, environmental damage can occur.

Another potential atmospheric impact is that caused by drift. Drift is that fraction of the circulating cooling water exhausted to the atmosphere as water droplets. Upon leaving the cooling system, drift rises and may descend to the ground at various distances depending on local meteorological conditions. As the water droplets evaporate, all constituents in the water (primarily water treatment chemicals and dissolved salts) concentrate and, if deposited, can cause damage to nearby soils and vegetables, as well as to materials and equipment subject to corrosion.

\subsubsection{Land-Use, Aesthetic, and Noise Impacts}

Land-use, aesthetic, and noise impacts are those effects related to the quality and utilization of land required by the various closed-cycle cooling systems and the visual and noise impacts to the environment as a whole. The siting of closed-cycle cooling system on a tract of land effectively removes that land from other constructive uses. The land requirements may be relatively large. Impacts to the environment -- such as erosion, sedimentation, groundwater contamination, defoliation, and habitat modifications -- must be considered. In addition to these impacts, the noise generated by the various modes of closed-cycle cooling must be considered relative to background noise already present at the site. 
Visual impacts and aesthetics are factors that must also be taken into account when the environmental impacts of closed-cycle cooling systems are reviewed. The type and elevation of the cooling system to be used, prominent viewpoints, ground cover, and subjective considerations by the affected population must be taken into account.

\subsection{MODELING TECHNIQUES FOR IMPACT ASSESSMENT}

The potential impacts of cooling systems to the environment are described in previous sections. Proper assessment of those impacts is essential in the operation of nuclear power plants. Methodologies including field, laboratory, statistical, and modeling are available for aids in (1) designing the appropriate discharge configurations, (2) determining the environmental impacts of alternative designs, and (3) determining if regulatory standards are satisfied. In this section, the use of mathematical modeling is discussed in the context of assessing environmental impacts.

\subsubsection{Model Application and Selection}

Model application for impact assessment can be divided into three stages: (1) site-selection period, (2) preconstruction period, and (3) preoperation period. During the site-selection process, the model is used to provide a site-characterization/scoping study for comparing alternative sites and for determining an appropriate plant site. After selecting the site location and prior to the construction of the plant, a more detailed calculation is needed for designing the optimum discharge configurations and for assessing the potential impacts. The results of this preconstruction analysis constitute part of the information needed for the utility company to apply for a plant construction permit. After the plant is constructed, model application is often necessary for updating the impact analysis. It is therefore obvious that the model application is important in the design, construction, and operation processes of a nuclear power plant. The question is how to choose an appropriate model.

A good model generally includes correct physical assumptions and should be able to be applied to the case under consideration with little or no schematization necessary. The model should be easy to use and not costly. In addition, model verification should be available for cases similar to the one under study, and the input data required by the model should be known. These model characteristics are sometimes difficult to establish. Therefore, selection of an appropriate model requires proper balancing of the project needs, the model limitations, and the availability of input information. For an idealized situation, the use of simple models can often provide sufficiently good results. For 
complicated conditions, it would be necessary to use complex models. However, complex models generally require more input data than what may be available. In this case, conservative assumptions would be needed for the modeling. The model predictions would have to be verified later to ensure that impacts predicted by the model are greater than the actual situation.

\subsubsection{Methodology of Modeling}

The methodology of modeling is dictated by the regulatory requirements and is different depending on the types of cooling systems. For predicting thermal plumes resulting from heated-water discharges into large lakes, oceans, and other open water bodies, it is necessary to divide measured hydrologic data at the site into ranges in order to best represent different plume conditions. A representative case is then chosen from each data range and used in the model for predicting the isotherms required by the temperature standards. To represent extreme cases, it is also necessary to assume that the plant is under full load and that the worst environmental conditions are occurring.

For thermal discharges into small cooling ponds, one should first obtain a 1- to 10-year meteorological record from the site or the nearest airport. The model is then used to predict pond temperature field and pond discharge temperatures as a function of time. The pond discharge temperatures might further be used to predict blowdown plume temperatures in the river.

For cooling tower impact modeling, one should first acquire an accurate model for single-case calculations for visible plume rise, drift deposition, fogging, icing, and relative humidity increase on ground. The next step is to develop about 100 representative categories with corresponding frequencies of occurrence by season (or annual) and by wind direction. The plume/drift model is then run 100 times, suitably weighing output by frequencies of occurrence previously established. Finally, computed predictions, e.g., shadowing and drift, are plotted by means of isopleths about the cooling towers.

\subsubsection{Recommended Models}

Several mathematical models have been developed to describe and predict the thermal impacts resulting from various types of cooling systems. The models are listed in Table 4.1 for both once-through and closed-cycle cooling systems. Most of the models have been reviewed by Silberman and Stefan (1970), Benedict et al. (1974), Dunn et al. (1975), and Policastro et al. $(1979,1980)$. In view of these previous reviews and an almost prohibitively large amount of literature on the subject 
Table 4.1. Recommended Models for Thermal Impact Assessment

\begin{tabular}{|c|c|c|}
\hline System & Discharge Condition & Recommended Model \\
\hline \multirow[t]{3}{*}{$\begin{array}{l}\text { Once-through } \\
\text { cooling }\end{array}$} & $\begin{array}{l}\text { Shoreline surface } \\
\text { discharge }\end{array}$ & $\begin{array}{l}\text { Pritchard (1971) } \\
\text { Stolzenbach and Harleman (1971) } \\
\text { Shirazi and Davis (1974) } \\
\text { Eraslan (1975) } \\
\text { Waldrop and Farmer (1975) }\end{array}$ \\
\hline & $\begin{array}{l}\text { Single-port submerged } \\
\text { discharge }\end{array}$ & $\begin{array}{l}\text { Koh and Fan (1970) } \\
\text { Hirst (1971) } \\
\text { Shirazi and Davis (1972) }\end{array}$ \\
\hline & $\begin{array}{l}\text { Multiport submerged } \\
\text { diffuser discharge }\end{array}$ & $\begin{array}{l}\text { Adams (1972) } \\
\text { Jirka and Harleman (1973) } \\
\text { Lee et al. (1977a) } \\
\text { Brocard et al. (1980) }\end{array}$ \\
\hline \multirow[t]{2}{*}{$\begin{array}{l}\text { Discharge into } \\
\text { cooling ponds } \\
\text { or lakes }\end{array}$} & Deep ponds & $\begin{array}{l}\text { Ryan and Harleman (1972) } \\
\text { Watanabe et al. (1975) } \\
\text { Lee et al. (1977b) } \\
\text { Jirka et al. (1977) }\end{array}$ \\
\hline & Shallow ponds & $\begin{array}{l}\text { Watanabe and Jirka (1977) } \\
\text { Cerco (1977) } \\
\text { Edinger and Buchak (1977) }\end{array}$ \\
\hline \multirow[t]{3}{*}{$\begin{array}{l}\text { Cooling tower } \\
\text { effluents }\end{array}$} & Single-tower plume & $\begin{array}{l}\text { Hanna (1975) } \\
\text { Wigley and Slawson (1975) } \\
\text { Winiarski and Frick (1976) }\end{array}$ \\
\hline & Multiple-tower plume & $\begin{array}{l}\text { Motor Columbus (1977) } \\
\text { Orville et al. (1977) }\end{array}$ \\
\hline & Drift & $\begin{array}{l}\text { Slawson and Wigley (1976) } \\
\text { Motor Columbus (1977) } \\
\text { LaVerne (1977) }\end{array}$ \\
\hline \multirow[t]{2}{*}{ Spray cooling } & Spray canals & $\begin{array}{l}\text { Porter and Chen (1974) } \\
\text { Porter (1974) }\end{array}$ \\
\hline & Spray ponds & $\begin{array}{l}\text { Elgawhary and Rowe (1971) } \\
\text { Hoffman }(1973) \\
\text { Elgawhary }(1974)\end{array}$ \\
\hline
\end{tabular}


of heated discharges, no attempt is made here to include all of the related references. Rather, only those models that are commonly used for environmental impact assessment are enumerated.

\section{BENEFICIAL USE OF WASTE HEAT}

The need for improved energy utilization and potential beneficial uses of thermal discharges have stimulated a continuing examination of various methods for productively using energy currently wasted to the environment. Waste heat generated from power plants is usually in the $60-97^{\circ} \mathrm{F}\left(16-36^{\circ} \mathrm{C}\right)$ temperature range and is available in large quantities. Such waste heat can be used for agricultural purposes such as heating greenhouse and animal shelters, providing frost protection in open field agriculture, or maintaining optimum temperatures for the growth and production of seafood or $f$ ish in aquaculture.

Beneficial use of waste heat for greenhouse heating has been demonstrated worldwide with projects in the United States, Canada, England, and Europe. Results of these projects have shown that it is both technically and economically feasible to utilize condenser waste heat for commercial greenhouse heating. In other agricultural applications, a number of farm animal studies have been conducted in the United States during the past several years in which environmental temperature is an important factor in increasing the feed efficiency and the growth-rate of poultry and swine. In engineering studies, it has been noted that the waste heat from a 1,000-MWe nuclear plant is sufficient to farrow or finish about $10 \mathrm{million}$ hogs per year. In outdoor applications of warm water for agricultural purposes, the states of Washington and Oregon in the United States have successfully studied the possibilities of warm water discharge for irrigation and frost protection purposes in that area.

Aquacultural use of waste heat has been practiced for centuries in Japan and more recently in the United States. The Japanese have carried out culture experiments with shrimp, eel, yellow tail, sea bream, abalone, and white fish using thermal effluents from steam-electric power-generating stations. Results of the experiments indicate that growth rates are much higher in the $13-14^{\circ} \mathrm{F}\left(7-8^{\circ} \mathrm{C}\right)$ warmer discharge water than at natural temperatures. In the United States, catfish production operations have been carried out in conjunction with power plant operations in the states of Tennessee and Texas. Perhaps the most successful application of waste heat in mariculture is the commercial operation of oyster culture using thermal effluents of Long Island Lighting Company. This operation has been extended to raising clams as 
well as oysters, and about 1 million clams per day are being raised in the heated discharge lagoon.

At present, the amount of waste heat utilized for beneficial use in agriculture and aquaculture represents only a small fraction of the total waste heat generated from the power plants. Therefore, the primary incentive for the beneficial use of discharged waste heat is economic rather than as a solution to thermal pollution problems. Large-scale demonstration projects are needed to stimulate a greater use of waste heat on a broader scale in the future.

\section{REFERENCES}

Adams, E.E. 1972. Submerged Multiport Diffusers in Shallow Water with Current. S.M. Thesis, Department of Civil Engineering, Massachusetts Institute of Technology, Cambridge, Massachusetts.

Benedict, B.A., J.L. Anderson, and E.L. Yandell, Jr. 1974. Analytical Modeling of Thermal Discharges: A Review of the State of the Art. ANL/ES-18. Argonne National Laboratory, Argonne, Illinois.

Brocard, D.N., C.H. Beauchamp, and S.K. Hsu. 1980. Mathematical model for staged diffuser discharge. In Proceedings of the Speciality Conference on Computer and Physical Modeling in Hydraulic Engineering, Chicago, Illinois. pp. 154-165.

Cerco, C. 1977. Experimental and Analytical Study of the Design of Shallow Cooling Ponds. M.S. Thesis. Department of Civil Engineering, Massachusetts Institute of Technology, Cambridge, Massachusetts.

Downs, D.D., and K.R. Meddock. 1974. Engineering application of fish behavior studies in the design of intake systems for coastal generating stations. Proceedings, American Society of Chemical Engineers Conference. pp. 125-140.

Dunn, W.E., A.J. Policastro, and R.A. Paddock. 1975. Surface Thermal Plumes: Evaluation of Mathematical Models for the Near and Complete Field. ANL/WR-75-3. Argonne National Laboratory, Argonne, Illinois. 2 parts. 
Edinger, J.E., and E.M. Buchak. 1977. A Hydrodynamics Two-Dimensional Reservoir Model. Development and Test Application to Sutton Reservoir, Elk River, West Virginia. U.S. Army Engineer Division, Ohio River, Cincinnati, Ohio.

Elgawhary, A.M. 1974. Design considerations and thermal performance of spray cooling systems for large power and chemical plants. Paper No. $74 \mathrm{e}$ presented at the $67 \mathrm{th}$ Annual Meeting, American Institute of Chemical Engineers, Washington, D.C., December 1-5, 1974.

Elgawhary, A.M., and A.M. Rowe. 1971. Spray pond mathematical model for cooling fresh water and brine. In Environmental and Geophysical Heat Transfer, Proceedings of a Symposium. HTD--Vol. 4. American Society of Mechanical Engineers, New York. pp. 1-8.

Eraslan, A. 1975. Transient, Two-Dimensional, Discrete-Element, FarField Transport Model for Thermal Impact Analysis of Power Plant Discharges in Coastal and Offshore Regions. Part I: General Description of Mathematical Model and Results of an Application. ORNL-4940. Oak Ridge National Laboratory, Oak Ridge, Tennessee.

Federal Energy Regulatory Commission. 1978. Steam-Electric Plant Air and Water Quality Control Data for the Year Ended December 31, 1974. DOE/FERC-0018. Washington, D.C.

Hanna, S.R. 1975. Predicted and Observed Cooling Tower Plume Rise and Visible Plume Length at the John E. Amos Power Plant. NOAA Atmospheric Turbulence and Diffusion Laboratory, Oak Ridge, Tennessee.

Hirst, E.A. 1971. Analysis of Round, Turbulent Buoyant Jets Discharged to Flowing Stratified Ambients. ORNL-4685. Oak Ridge National Laboratory, Oak Ridge, Tennessee. $37 \mathrm{pp}$.

Hoffman, D.P. 1973. Spray cooling for power plants. In Proceedings of the American Power Conference. Vol. 35, p. 702.

Jirka, G., D. Brocard, K. Octavio, M. Watanabe, and D.R.F. Harleman. 1977. Analysis of Cooling Effectiveness and Transient Long-Term Simulations of a Cooling Lake With Application to the North Anna Power Station. Report No. 232. Ralph M. Parsons Laboratory for Water Resources and Hydrodynamics, Massachusetts Institute of Technology, Cambridge, Massachusetts. 
Jirka, G.H., and D.R.F. Harleman. 1973. The Mechanics of Submerged Multiport Diffusers for Buoyant Discharges in Shallow Water. Report No. 169. Ralph M. Parsons Laboratory for Water Resources and Hydrodynamics, Massachusetts Institute of Technology, Cambridge, Massachusetts.

Koh, R.C.Y., and L.N. Fan. 1970. Mathematical Models for the Prediction of Temperature Distributions Resulting from the Discharge of Heated Water in Large Bodies of Water. EPA Water Pollution Control Research Series 16130 DWO. 219 pp.

LaVerne, M.E. 1977. The Oak Ridge Fog and Drift Code (ORFAD) User's Manual. ORNL/TM-5021. Oak Ridge National Laboratory, Oak Ridge, Tennessee.

Lee, J.H., G.H. Jirka, and D.R.F. Harleman. 1977a. Modeling of Unidirectional Thermal Diffusers in Shallow Water. Energy Lab. Report No. MIT-EL 77-016. Ralph M. Parsons Laboratory For water Resources and Hydrodynamics, Massachusetts Institute of Technology, Cambridge, Massachusetts. 304 pp.

Lee, S., S. Sengupta, and S.K. Mathavan. 1977b. Three-Dimensional Numerical Model for Lake Belews. Department of Mechanical Engineering, University of Miami, Coral Gables, Florida.

Motor Columbus Consulting Engineers and the Environmental Systems Corporation. 1977. The KUMULUS Model for Plume and Drift Deposition Calculated for Indian Point No. 2. Knoxville, Tennessee.

National Economic Research Associates, Inc., and Stone \& Webster Engineering Corporation. 1978. Thermal Control Cost Factors. Prepared for Utility Water Act Group.

National Technical Advisory Committee. 1968. Water Quality Criteria. Federal Water Pollution Control Administration, U.S. Department of the Interior, Washington, D.C.

Orville, H.D., L.E. May, and J.H. Hirsch. 1977. Application of Cloud Model to Cooling Tower Plume and Cloud. Institute of Atmospheric Sciences, South Dakota School of Mine and Technology, Rapid City, South Dakota. 
Paddock, R.A., and J.D. Ditmars. 1978. An Assessment of the OnceThrough Cooling Alternatives for Central Steam-Electric Generating Stations. ANL/WR-78-5. Argonne National Laboratory, Argonne, Illinois.

Policastro, A.J., R.A. Carhart, S.E. Ziemer, and K. Haake. 1979. Evaluation of Mathematical Models for Characterizing Plume Behavior from Cooling Towers. Vol. 1 - Dispersion from Single and Multiple Source Natural Draft Cooling Towers. NUREG/CR-1581, Vol. 1. Prepared by Argonne National Laboratory, Argonne, Illinois, for U.S. Nuclear Regulatory Commission.

Policastro, A.J., W.E. Dunn, M.L. Breig, and J.P. Ziebarth. 1980. Evaluation of Mathematical Models for Characterizing Plume Behavior from Cooling Towers. Vol. 2 - Salt Drift Deposition from Natural Draft Cooling Towers. NUREG/CR-1581, Vol. 2. Prepared by Argonne National Laboratory, Argonne, Ill., for U.S. Nuclear Regulatory Commission.

Porter, R.W. 1974. Analytical Solution for Spray-Canal Heat and Mass Transfer. IIT Fluids and Heat Transfer Report R74-1. Illinois Institute of Technology, Chicago, Illinois.

Porter, R.W., and K.H. Chen. 1974. Heat and mass transfer of spray canals. J. Heat Transfer 98:286-291.

Pritchard, D.W. 1971. Design and siting criteria for once-through cooling systems. Presented at 68th Annual Meeting, American Institute of Chemical Engineers, Houston, Texas.

Public Service Company of New Hampshire. 1973. Seabrook Station Environmental Report - Construction Permit Stage.

Ryan, P., and D.R.F. Harleman. 1973. An Analytical and Experimental Study of Transient Cooling Pond Behavior. Report No. 161. Ralph M. Parsons Laboratory for Water Resources and Hydrodynamics, Massachusetts Institute of Technology, Cambridge, Massachusetts.

Schuler, V.J., and L.E. Larson. 1974. Experimental studies evaluating aspects of fish behavior as parameters in the design of generating station intake systems. Proceedings of the American Society of Chemical Engineers Conference. pp. 80-97. 
Schuler, V.J., and L.E. Larson. 1975. Improved fish protection at intake systems. J. Environ. Eng. Div. Am. Soc. Chem. Eng. 101(EEG): $897-910$.

Shirazi, M.A., and L.R. Davis. 1972. Workbook of Thermal Plume Prediction -- Vol. 1, Submerged Discharge. EPA-R2-72-005a. National Environmental Research Center, U.S. Environmental Protection Agency, Corvallis, Oregon.

Shirazi, M.A., and L.R. Davis. 1972. Workbook of Thermal Plume Prediction -- Vol. 2, Surface Discharges. EPA-R2-72-005b. Environmental Protection Technology Series, U.S. Environmental Protection Agency, Corvallis, Oregon.

Silberman, E., and H. Stefan. 1970. Physical (Hydraulic) Modeling of Heat Dispersion in Large Lakes: A Review of the State of the Art. ANL/ES-2. Center for Environmental Studies, Argonne National Laboratory, Argonne, Illinois.

Slawson, P.R., and T.M.L. Wigley. 1976. Calculation of cooling tower drift deposition. In K.E. Noll and W.T. Davis (eds.), Power Generation: Air Pollution Monitoring and Control. Ann Arbor Science Publications, Ann Arbor, Michigan.

Stolzenbach, K., and D.R.F. Harleman. 1971. An Analytical and Experimental Investigation of Surface Discharges of Heated Water. Report No. 135. Ralph M. Parsons Laboratory for Water Resources and Hydrodynamics Laboratory, Massachusetts Institute of Technology, Cambridge, Massachusetts.

U.S. Environmental Protection Agency. 1977. Interagency 316(a) Technical Guidance Manual and Guide for Thermal Effects Sections of Nuclear Facilities Environmental Impact Statements. Office of Water Enforcement, Permits Division, Industrial Permits Branch, Washington, D.C.

U.S. Environmental Protection Agency. 1979. Closed-Cycle Cooling Systems for Steam-Electric Power Plants. EPA-600/7-79-001.

U.S. Nuclear Regulatory Commission. 1974. Final Environmental Impact Statement Related to the Proposed Pilgrim Nuclear Power Station, Unit 2. Docket No. 50-471. Directorate of Licensing, Washington, D.C. 
Utility Water Act Group. 1978a. A Survey of Operating Experience with Saltwater Closed Cycle Cooling Systems.

Utility Water Act Group. 1978b. Biological Effects of Once-Through Cooling.

Waldrop, W.R., and R.C. Farmer. 1975. Thermal effluents -- river interactions. In Proceedings of the XVIth Congress, International Association for Hydraulic Research, Sao Paulo, Brazil. Vol. 3, pp. 221-229.

Watanabe, M., D.R.F. Harleman, and J.J. Connor. 1975. Finite Element Model for Transient Two-Layer Cooling Pond Behavior. Technical Report No. 202. Ralph Parsons Laboratory for Water Resources and Hydrodynamics, Massachusetts Institute of Technology, Cambridge, Massachusetts.

Watanabe, M., and S.H. Jirka. 1977. A longitudinal dispersion model for shallow cooling ponds. In Proceedings of the Waste Heat Management and Utilization Conference, University of Miami, Miami, Florida.

Weight, R.H. 1958. Ocean cooling eater system for $800 \mathrm{MW}$ power station. J. Power Div. Proc. Am. Soc. Civil Eng. Pap. 1888:1-22.

Wigley, T.M., and P.R. Slawson. 1975. The effect of atmospheric conditions on the length of visible cooling tower plumes. Atmos. Environ. 9:437-445.

Winiarski, L., and W. Frick. 1976. A Cooling Tower Plume Model. EPA-600/3-76-100. Pacific Northwest Environmental Research Laboratory, U.S. Environmental Protection Agency, Corvallis, Oregon. 